\title{
Inducible Nephrin Transgene Expression in Podocytes Rescues Nephrin-Deficient Mice from Perinatal Death
}

\author{
Juuso Juhila, ${ }^{\star \dagger}$ Markus Lassila, ${ }^{*}$ \\ Ramon Roozendaal, ${ }^{\ddagger}$ Eero Lehtonen, ${ }^{\S}$ \\ Marcel Messing, ${ }^{*}$ Brigitte Langer, ${ }^{\text {"I }}$ \\ Dontscho Kerjaschki, ${ }^{\text {Tा }}$ J. Sjef Verbeek, ${ }^{\ddagger}$ \\ and Harry Holthofer* ${ }^{\star \dagger}$ \\ From the Haartman Institute, "Department of Bacteriology and \\ Immunology, University of Helsinki, Helsinki, Finland; the Centre \\ for Bioanalytical Sciences, ${ }^{\dagger}$ Dublin City University, Dublin, \\ Ireland; the Department of Human Genetics, ${ }^{\ddagger}$ Leiden University \\ Medical Center, Leiden, the Netherlands; the Haartman Institute, $\$$ \\ Department of Pathology and Experimental Animal Centre, \\ University of Helsinki, Helsinki, Finland; and the Clinical \\ Institute of Pathology, "Medical University Vienna, Vienna, \\ Austria
}

Mutations leading to nephrin loss result in massive proteinuria both in humans and mice. Early perinatal lethality of conventional nephrin knockout mice makes it impossible to determine the role of nephrin protein in the adult kidney and in extra-renal tissues. Herein, we studied whether podocyte-specific, doxycycline-inducible, rat nephrin expression can rescue nephrin-deficient mice from perinatal lethality. Fourteen littermates out of 72 lacked endogenous nephrin and expressed transgenic rat nephrin. Six of these rescued mice survived until 6 weeks of age, whereas the nephrin-deficient pups died before the age of 5 days. The rescued mice were smaller, developed proteinuria, and showed histological abnormalities in the kidney. Despite foot process effacement, slit diaphragms were observed. Importantly, the expression and localization of several proteins associated with the signaling capacity of nephrin or the regulation of the expression of nephrin were changed in the podocytes. Indeed, all rescued mice showed impaired locomotor activity and distinct histological abnormalities in the cerebellum, and the male mice were also infertile and showed genital malformations. These observations are consistent with normal nephrin expression in the testis and cerebellum. These observations indicate that podocyte-specific expres- sion of rat nephrin can rescue nephrin-deficient mice from perinatal death, but is not sufficient for full complementation. (Am J Patbol 2010, 176:51-63; DOI: 10.2353/ajpath.2010.080843)

Children born with congenital nephrotic syndrome of the Finnish type (CNF) suffer from severe kidney disease associated with impaired podocyte function. Before current transplantation therapy, these children died within a few months after birth due to massive proteinuria. ${ }^{1}$ Positional cloning revealed that CNF is caused by a defect in a single gene (NPHS1) encoding the slit diaphragm-specific protein nephrin. ${ }^{2}$ In the Finnish population, two main mutations in the nephrin gene, Fin major $_{\text {and Fin }}$ minor have been reported. ${ }^{2}$ The most common mutation, Fin major, is a deletion in exon 2 that results in a frameshift with a stop codon within the same exon, causing complete loss of the nephrin protein. ${ }^{3}$ The other Finnish mutation, Fin minor, is a nonsense mutation in exon 26, which leads to a large deletion of the intracellular domain of nephrin. ${ }^{3}$ Both mutations cause the same clinical symptoms, including massive proteinuria, edema, and low birth weight, and the kidney shows striking histological abnormalities. ${ }^{1,4-7}$

Consistent with the human CNF phenotype, the majority of conventional nephrin knockout (KO) mice die in

Supported by grants from the Einar and Karin Stroems Foundation, the Finnish Kidney Foundation, the Alfred Kordelin Foundation, the Orion Pharma Foundation, the Jalmari and Rauha Ahokas Foundation, the Paavo Nurmi Foundation, European Union (QLGI-CT-2000-00619 and ADDNET LSHB-CT-2003-503364 and Dia Na LSHB-CT-2006-037681), the Sigrid Juselius Foundation, and the Finnish Diabetes Foundation.

J.S.V. and H.H. contributed equally to the manuscript.

Accepted for publication September 11, 2009.

Part of this work was presented at the American Society of Nephrology Meeting, Philadelphia, PA, November 8-11, 2005 and in San Diego, CA, November 14-19, 2006.

Supplemental material for this article can be found on http://ajp. amjpathol.org.

Address reprint requests to Harry Holthofer, M.D., Ph.D., Centre for Bioanalytical Sciences (CBAS), Dublin City University (DCU), Glasnevin, Dublin 9, Ireland. E-mail: harry.holthofer@dcu.ie. 
utero and the remaining minority die within a few days after birth. Their podocytes show morphological abnormalities similar to the abnormalities found in CNF patients including severe foot process effacement and absence of slit diaphragms. ${ }^{8,9}$ Due to perinatal lethality, conventional nephrin $\mathrm{KO}$ mice are not suitable for a detailed analysis of the biological function of nephrin within the adult kidney and in the other organs in which nephrin is expressed in mice.

Nephrin protein consists of an extracellular part with immunoglobulin-like domains that is involved in the maintenance of the slit diaphragm structure, and an intracellular part required for signaling. ${ }^{10}$ Despite the fact that several aspects of the structure and function of nephrin in the slit diaphragms are well characterized, some key questions still remain to be answered, including: a) What is the role of nephrin and its intracellular signaling cascade during the development of the glomerular filtration barrier, and in the maintenance and repair of the integrity of the slit diaphragm in adults? and, b) What is the function of nephrin in the other organs in which nephrin is expressed?

To study the above-mentioned functions, we generated a transgenic mouse line with a doxycycline-inducible rat nephrin transgene expressed specifically in the podocytes, and subsequently back-crossed this line onto a nephrin-deficient background. The transgenic expression of rat nephrin rescued the lethal phenotype of the conventional nephrin $\mathrm{KO}$ mouse. However, in the rescued mice abnormalities characteristic for the CNF phenotype were observed, including growth retardation, proteinuria, and podocyte foot process effacement in the kidney; the expression and localization of specific nephrin-associated proteins in the podocytes were also changed. In addition, the reproductive organs and brain, the other organs in which nephrin normally is expressed in mice, showed abnormalities that may contribute to the manifestation of the phenotype.

\section{Materials and Methods}

\section{Podocyte-Specific Doxycycline-Inducible Rat Nephrin Construct}

The p2.5PodocinpnlacF plasmid containing $2.5 \mathrm{~kb}$ of the genomic sequence of the human podocin (NPHS2) gene located $5^{\prime}$ to the translation initiation codon, was kindly provided by Dr. Lawrence Holzman, at the University of Michigan, Ann Arbor, Ml. ${ }^{11,12}$ The "Core" construct was provided by W.H. Lee, at the University of Texas Health Science Center at San Antonio, San Antonio, TX. ${ }^{13}$ The original reverse tetracycline transactivator of the core construct was modified as reported previously. ${ }^{14}$ The resulting construct was stable and was named RRC-M2.

In the unique Xbal site of the p2.5PodocinpnlacF plasmid, a linker (sense: 5'-CTAGCAGATCTAAGCAGTCGACA-3' and antisense: 5'-CTAGTGTCGACTGCTTAGATCTG-3') was cloned containing a Sall site. The p2.5PodocinpnlacF plasmid was cut with $\mathrm{Ncol}$, and the sticky ends blunted using T4 polymerase (New England Biolabs, Ipswich, MA). Subsequently, the DNA was cut with
Sall and the resulting $2.5 \mathrm{~kb}$ Sall-blunted Ncol fragment, containing the NPHS2 promoter, was cloned into the SallSmil sites of the RRC-M2 construct (I).

In parallel, RRC-M2 plasmid (II) was digested by XholNotl digestion and this $2.5 \mathrm{~kb}$ fragment was subcloned to pBRGEM11plasmid. A linker (sense: 5'-CTAGCAGATCTAAGCAGTCGACA-3' and antisense: 5'-CTAGTGTCGACTGCTTAGATCTG-3') containing a Smil site was cloned into the pBRGEM11plasmid that was previously digested with Sacll.

In parallel, a linker (sense: 5'-CTAGCAGATCTAAGCAGTCGACA-3' and antisense: 5'-CTAGTGTCGACTGCTTAGATCTG-3') containing an additional Smil restriction site was cloned into the Spel site of the pBKCMVneph plasmid, containing full-length $3.7 \mathrm{~kb}$ of the sequence of rat NPHS1 cDNA. The polyA tail (pA) was cloned to the $3^{\prime}$ end of the NPHS1 cDNA by using Scal-Notl digestions. Subsequently, the construct was cut with Smil-Notl and the resulting $4.3 \mathrm{~kb}$ fragment, containing both nephrin cDNA and pA was cloned into the Smil-Notl sites of the RRC-M2 vector (II).

The pGEM-T-Easy (Promega, Madison, WI) vector contained $572 \mathrm{bp}$ of the sequence of the $\beta$-globin intron. This was amplified by PCR and released by EcoRI digestion. The cut fragment was blunted using T4 polymerase. The resulting blunted fragment of the $\beta$-globin intron was cloned into the Smil site of the RRC-M2 vector, which contained the NPHS1 cDNA and pA (II).

Finally, the Sall-Notl fragment containing tetO-CMV-Bglobin-rat NPHS1-pA sequence (II) was cloned into the Xhol-Notl sites of the RRC-M2 construct (I) that contained the podocin promoter. The final podocyte-specific doxycycline inducible construct containing full-length rat nephrin cDNA sequence was called JRC-rNephrin (III) and is presented in Figure $1 \mathrm{~A}$.

For microinjection, the insert of JRC-rNephrin was purified by digesting the plasmid with Notl, and subsequent gel electrophoresis, followed by DNA extracted using the QIAEX II Gel Extraction Kit (Qiagen GmbH, Hilden, Germany).

\section{Ethics}

Experiments with animals were performed according to the European Communities Council Directive 86/609/ EEC, and the protocols of the experiments were approved by the local ethical committees for laboratory animal welfare.

\section{Generation of Podocyte-Specific Doxycycline Inducible Rat Nephrin Transgenic Mice}

The JRC-rNephrin construct was introduced into the pronuclei of fertilized oocytes from FVB/N mice by microinjection using standard procedures. The resulting founders (rNeph) were back-crossed on ICR wild-type mice for five generations. The ICR strain was chosen, because the Nephrin KO $\left(\mathrm{mNeph}^{-1-}\right)$ mouse line used in these studies, was already back-crossed to ICR background. The ICR outbred strain females have more littermates and better maternal care compared with normally used C57BI/6 inbred mouse strain. In all experiments, the littermate controls were used. 


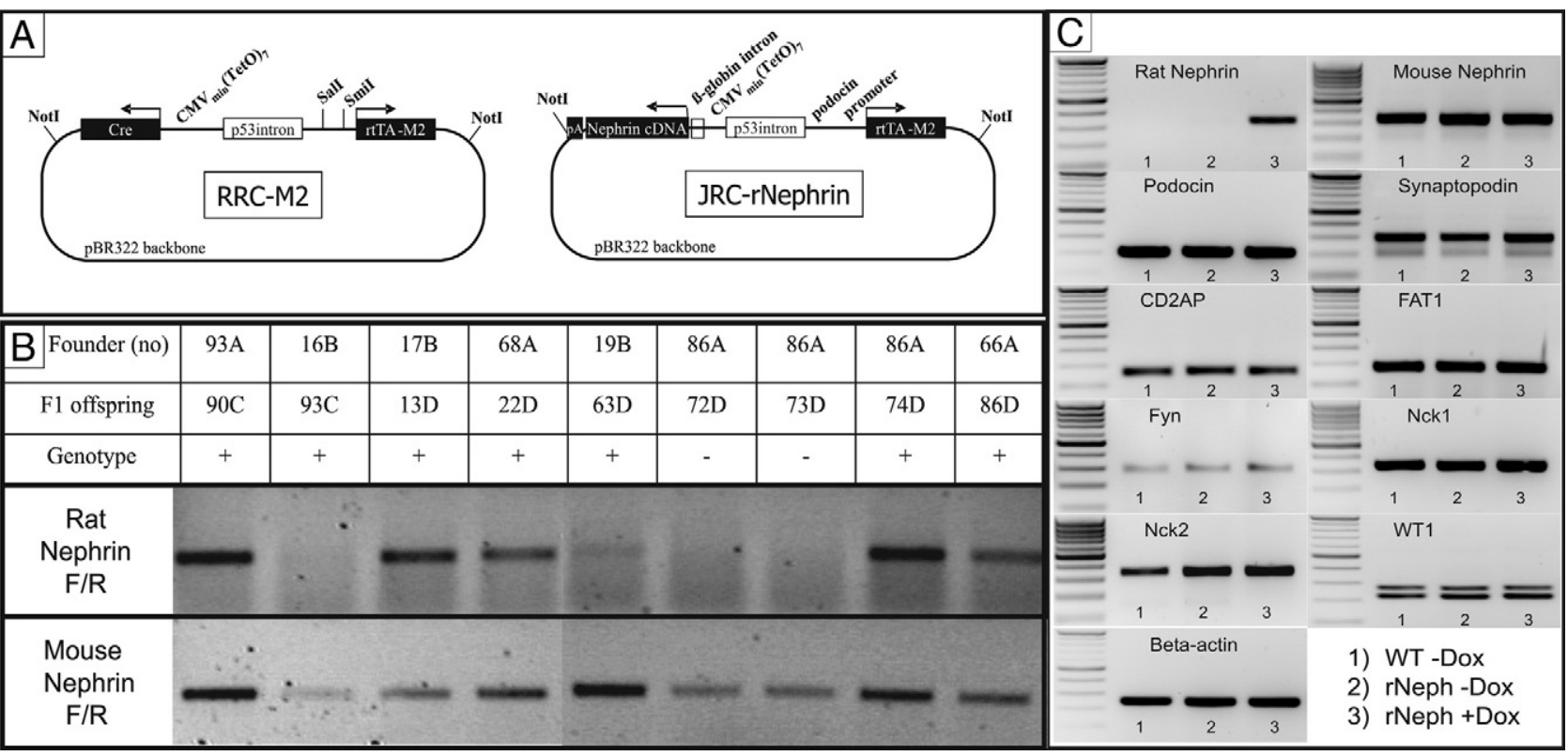

Figure 1. The rNephrin transgenic mouse. A: The JRC-rNephrin transgene construct: In a binary reverse doxycycline-regulated expression vector an NPHS2 (podocin) promoter drives the expression of the recombinant inducible transcription factor reverse tetracycline transactivator (M2). In the presence of doxycycline, reverse tetracycline transactivator binds to the tetO7 element linked to a minimal CMV promoter that drives the expression of rat nephrin cDNA. B: Rat- and mouse-specific nephrin mRNA expressions in JRC-rNephrin (rNeph) mouse kidneys isolated from nine founder-lines (93A - 66A) analyzed by RT-PCR. C: RT-PCR of mRNA from the kidney cortex of the selected JRC-rNephrin founder-line (86A): 1) Wild-type mouse without doxycycline, 2) rNeph mouse without doxycycline, and 3) rNeph mouse with doxycycline. Total RNA was isolated from kidneys collected from adult mice at the age of 10 to 12 weeks after 2 weeks of doxycycline $(0.2 \mathrm{mg} / \mathrm{ml})$ administration. PCR was performed using primers presented in Table 2 . Similar results were obtained with three independent experiments with three mice in each genotype.

Transgenic mice were identified by PCR on genomic DNA isolated from tail biopsies (50 to $100 \mathrm{ng}$ ), using Rat NephrinForward: (5'-AGGTACAGCCTGGAAGGAGATC$3^{\prime}$ ), and RatNephrinReverse: (5'-TCCTCTGATCCCTCATTCACAT- $3^{\prime}$ ) primers. PCR was performed as follows, 35 cycles at $95^{\circ} \mathrm{C}(30 \mathrm{~s}), 54^{\circ} \mathrm{C}(30 \mathrm{~s})$, and $72^{\circ} \mathrm{C}(30 \mathrm{~s})$, and a final extension at $72^{\circ} \mathrm{C}$ for 5 minutes and the DNA product was analyzed with standard agarose gel electrophoresis. ${ }^{14}$

\section{Generation of Endogenous Nephrin Deficient Mice with Transgenic Rat Nephrin Expression}

Mice from selected rNeph founder-line (86A) were crossbred with $\mathrm{mNeph}^{+/-}$mice to produce litters that are heterozygote for endogenous nephrin deletion and carrying the rat transgene $\left(\mathrm{rNeph} / \mathrm{mNeph}^{+/-}\right) .^{9}$ In the presence of $2.0 \mathrm{mg} / \mathrm{ml}$ doxycycline in the drinking water, the F1 offspring (rNeph/mNeph ${ }^{+/-}$) was intercrossed to generate F2 offspring that lacked a functional endogenous nephrin gene, while still containing the inducible podocytespecific rat nephrin transgene ( $\mathrm{rNeph} / \mathrm{mNeph}^{-1-}$ ). The different genotypes were labeled as follows: 1) rNeph/ $\mathrm{mNeph}^{+/+}$, 2) rNeph/mNeph ${ }^{+/-}$, and 3) $\mathrm{rNeph} / \mathrm{mNeph}^{-/-}$.

Transgenic mice were identified by PCR on tail genomic DNA as described above. The presence of the $\mathrm{KO}$ and wild-type alleles of the mouse nephrin gene was determined using a PCR protocol described previously. ${ }^{9}$

\section{Doxycycline Administrations}

To test rat nephrin transgene expression, doxycycline was administrated in the drinking water for 2 weeks $(0.2$ $\mathrm{mg} / \mathrm{ml}$ in $5 \%$ sucrose) to 8 - to 10 -week-old rNeph male mice, as described earlier. ${ }^{14}$

To examine transgene expression during the embryonic development, doxycycline was administered in the drinking water $(2.0 \mathrm{mg} / \mathrm{ml}$ in $5 \%$ sucrose $)$ to the pregnant rNeph females from conception on, until embryos were obtained at embryonic days 11 (E11) and 14 (E14). The embryonic kidneys (metanephros) were dissected as described previously. ${ }^{15}$

To analyze whether transgenic rat nephrin expression in podocytes can rescue conventional nephrin $\mathrm{KO}$ mice from perinatal death, doxycycline was administered in the drinking water $(2.0 \mathrm{mg} / \mathrm{ml}$ in $5 \%$ sucrose $)$ to $\mathrm{rNeph} / \mathrm{mNeph}^{+/-} \mathrm{F} 1$ females while mating with rNeph/ $\mathrm{mNeph}^{+/-} \mathrm{F} 1$ males. Doxycycline administration with same dose was continued to females during their pregnancy. After the birth, littermates got doxycycline via mother's milk as has been proven earlier. ${ }^{16,17}$ After weaning at the age of 3 weeks, doxycycline was administered to all F2 littermates via the drinking water (2.0 $\mathrm{mg} / \mathrm{ml}$ in $5 \%$ sucrose).

\section{Primary Behavioral Screening}

Five-week-old rNeph/mNeph male mice from different genotypes were used for behavioral characterization. 
Table 1. Genotype Ratios, Body Weights, and Urine Protein Concentrations in the $\mathrm{rNeph} / \mathrm{mNeph}$ Mouse Line

\begin{tabular}{cccccc}
\hline Genotype & $\begin{array}{c}\text { Number of } \\
\text { mice birthed }\end{array}$ & $\begin{array}{c}\text { Body weight } \\
\text { 1w }(\mathrm{g})\end{array}$ & $\begin{array}{c}\text { Body weight } \\
6 \mathrm{w}(\mathrm{g})\end{array}$ & $\begin{array}{c}\text { Protein in urine } \\
3 \mathrm{w}(\mathrm{g} / \mathrm{L})\end{array}$ & $\begin{array}{c}\text { Protein in urine } \\
6 \mathrm{w}(\mathrm{g} / \mathrm{L})\end{array}$ \\
\hline $\mathrm{rNeph} / \mathrm{mNeph}^{+/+}$ & $18 / 72$ & $4.7 \pm 0.7$ & $25.4 \pm 5.3$ & $0.3-1.0$ & $0.3-1.0$ \\
$\mathrm{rNeph} / \mathrm{mNeph}^{+/-}$ & $40 / 72$ & $5.1 \pm 0.7$ & $25.7 \pm 4.8$ & $0.3-1.0$ & $0.3-1.0$ \\
$\mathrm{rNeph} / \mathrm{mNeph}^{-1-}$ & $14 / 72$ & $2.2 \pm 0.5^{\star * *}$ & $15.2 \pm 6.4^{* \star}$ & $\geq 3.0$ & $\geq 3.0$ \\
\hline
\end{tabular}

Statistical significant differences ( $n=5$ to 10 ) after LSD test compared with $\mathrm{rNeph} / \mathrm{mNeph}^{+/+}$group; ${ }^{* \star *} P<0.001$.

The used battery of behavioral observational tests was a modification of the Irwin procedure, ${ }^{18}$ in which a total of 40 separate measurements is performed for each animal (Shirpa Protocol, EMPReSS Project, Oxon, UK).

\section{Determination of Protein Level in Urine}

Spot urine samples were collected from at least five mice of each genotype starting at the age of 3 weeks. A semiquantitative analysis of the urinary protein levels was performed using the Uristix (Bayer, Bridgend, UK) protein assay as indicated in the Uristix test strip package modified, as previously described. ${ }^{9}$ The results are presented in Table 1.

\section{Histology}

After sacrifice by cervical dislocation, mouse tissues were immediately dissected and fixed in $4 \%$ formaldehyde and embedded in paraffin. Sections (2 to $3 \mu \mathrm{m}$ ) were cut, deparaffinized, and stained by H\&E using standard procedures.

For electron microscopic examination, kidney cortex samples were fixed in $1.5 \%$ glutaraldehyde in $0.1 \mathrm{~mol} / \mathrm{L}$ cacodylate buffer $(\mathrm{pH} 7.4)$ at room temperature for 2 hours. The samples were postfixed in 1\% osmium tetroxide in the same buffer for 1 hour and stained en bloc in $1 \%$ uranyl acetate in $10 \%$ ethanol for 1 hour, dehydrated in ethanol, and embedded in LX112. Semithin sections were stained with toluidine blue. Thin sections were stained with uranyl acetate and lead citrate and examined in a Jeol JEM 1200EX electron microscope.

For immunogold microscopy kidney cortex samples were fixed in formalin or Bouins' solution (Sigma-Aldrich, St. Louis, MO) and stored in $70 \% \mathrm{EtOH}$ at $4^{\circ} \mathrm{C}$ until the use. Small fixed tissue samples were embedded in acrylic resin Lowicryl K4M (Polysciences, Inc., War- rington, PA). Ultrathin sections collected on Formvarcarbon coated nickel grids were quenched in $0.1 \mathrm{~mol} / \mathrm{L}$ Tris containing 1\% bovine serum albumin for 10 minutes, followed by incubation in rabbit anti-rat Nephrin 1034 (diluted 1:25 in 1\% bovine serum albumin, 0.5\% Tween20, $0.1 \%$ Triton-X 100 in 0.1 mol/L Tris) for 2 hours at room temperature. After washing in $0.1 \mathrm{~mol} / \mathrm{L}$ Tris, slides were incubated for 1 hour at room temperature with $15 \mathrm{~nm}$ of gold-labeled goat anti-rabbit IgG (BBInternational, Gardiff, UK). Sections were stained with $2 \%$ aqueous uranyl acetate and lead citrate and examined with a JEOL JEM 1200 transmission electron microscope. Nephrin localization was analyzed in the kidney of one control rNeph/mNeph ${ }^{+/+}$mouse and one rescued rNeph/ $\mathrm{mNeph}^{-1-}$ mouse using electron micrographs. The areas analyzed were the slit diaphragm, the podocyte cytoplasmic area, and the podocyte membrane outside of slit diaphragm area. The number of gold particles were counted manually and expressed as the number/1000 $\mathrm{nm}$ length of podocyte membrane. Student's $t$-test was used for statistical analysis.

\section{Reverse Transcription PCR of Mouse Tissues}

Mice were sacrificed by cervical dislocation, and tissues were immediately dissected, snap frozen, and stored in liquid nitrogen until used for reverse transcription (RT)PCR, immunofluorescent staining, and immunoblotting experiments. For RT-PCR, tissues were homogenized using Fastprep instrument (Q. Biogene, Carlsbad, CA) according manufacturer's recommendation with the lysing matrixD columns (Q. Biogene). Total RNA was extracted and the RT reaction was performed as described previously. ${ }^{14}$ Tissue cDNA was amplified by PCR using the primers presented in Table 2. The PCR was performed as described above with 35 cycles.

Table 2. Summary of the Primers Used in PCR

\begin{tabular}{|c|c|c|c|}
\hline Copied cDNA & Forward primer & Reverse primer & Size of product \\
\hline Rat nephrin & 5'-CAGGTACAGCCTGGAAGGAGATC-3' & 5'-TССТСТGATСССТСАТTCACAT-3' & $335 \mathrm{bp}$ \\
\hline Mouse nephrin & $5^{\prime}-$ AGGTACAGCCTGGAAGGAGACA-3' & 5'-TCCTCTGATCCCTCATTCACGC-3' & 335 bp \\
\hline Podocin & 5'-CCAGCTTCGATACTTGCACA-3' & 5'-СTTTGCCСАTTCGCСТАTAA-3' & $210 \mathrm{bp}$ \\
\hline Synaptopodin & $5^{\prime}$-GCTGCTGGAGCACTGGGC-3' & 5'-TTGGAGAGCCTGGCTTTG-3' & 298 bp \\
\hline CD2AP & 5'-GTTGGGACTGTTTCCCTCAA-3' & 5'-TTTCTTTGGCTGTGCAACTG-3' & $172 \mathrm{bp}$ \\
\hline FAT1 & 5'-GTGACGGACGTTGAGGAAAT-3' & 5'-ACTGCTGTTCTGTGGTGTCG-3' & 182 bp \\
\hline Fyn & 5'-CGAACTACAACTTCCAC-3' & 5'-CTGGAGCCACGTAATTGCTG-3' & $279 \mathrm{bp}$ \\
\hline Nck1 & 5'-AAGGACACCTTAGGTATTGG-3' & $5^{\prime}$-AGAGAACCTACATGATCACC-3' & $311 \mathrm{bp}$ \\
\hline Nck2 & 5'-GAACCTCAAGGACACACTAG- 3' & $5^{\prime}$-CGTAGGCTCAGGAAGCTGGG-3' & $342 \mathrm{bp}$ \\
\hline WT1 & 5'-ATCAGATGAACCTAGGAG-3' & 5'-CTGGGTATGCACACATGA-3' & $270 \mathrm{bp}$ or $219 \mathrm{bp}$ \\
\hline Beta-actin & 5'-TTCCTTCTTGGGTATGGAAT-3' & $5^{\prime}$-GGCCAGGATGGAGCCACCGA-3' & $250 \mathrm{bp}$ \\
\hline
\end{tabular}




\section{Immunofluorescent Staining}

Immunofluorescent staining was performed as previously described. ${ }^{14}$ The following primary antibodies were used: protein A-purified rabbit intracellular anti-rat nephrin-intra (1034) polyclonal antibody (1:50), ${ }^{19}$ rabbit antipodocin polyclonal antibody (1:50; Sigma, St. Louis, MI), anti-synaptopodin monoclonal antibody (1:4; Progen Biotechnik $\mathrm{GmbH}$, Heidelberg, Germany), rabbit anti-CD2-associated protein (CD2AP) polyclonal antibody (1:500), ${ }^{20}$ rabbit anti-FAT1 polyclonal antibody (1:50), ${ }^{21}$ rabbit antiWT1 polyclonal antibody (1:50; C-19; Santa Cruz Biotechnology, Santa Cruz, CA), anti-Fyn polyclonal antibody (1:50; Santa Cruz Biotechnology), rabbit anti-Nck1 polyclonal antibody (1:100; Abcam, Cambridge, UK), and rabbit antiNck2 polyclonal antibody (1:100; Abcam).

The following secondary antibodies were used: affinitypurified tetramethylrhodamine B isothiocyanate-conjugated goat anti-rabbit IgG (1:200; Jackson ImmunoResearch Laboratories Inc, West Grove, PA) or affinity-purified fluorescein isothiocyanate-conjugated rabbit anti-mouse IgG (1:200; DakoCytomation, Glostrup, Denmark).

\section{Immunoblotting}

Mouse kidney cortices were lysed using a glass homogenizer in radioimmunoprecipitation assay buffer $(150 \mathrm{mmol} / \mathrm{L}$ $\mathrm{NaCl}, 1 \% \mathrm{NP} 40,0.5 \%$ deoxycholic acid, 0.1\% SDS, 50 $\mathrm{mmol} / \mathrm{L}$ Tris- $\mathrm{HCl}$ [pH 8], 0.02\% $\mathrm{NaN}_{3}$ ) supplemented with Complete, Mini, EDTA-free proteinase inhibitor cocktail (Roche Molecular BioChemicals, Mannheim, Germany) on ice. Insoluble material was removed by centrifugation at $15,800 \times g$ at $4^{\circ} \mathrm{C}$ for 15 minutes and total protein concentrations were measured. Samples of $75 \mu \mathrm{g}$ were resolved by SDS-polyacrylamide gel electrophoresis on 10\% gels and were transferred on nitrocellulose membranes (Amersham Biosciences), and blocked with Odyssey blocking buffer (LI-COR Biosciences GmbH, Bad Homburg, Germany) at room temperature for 1 hour. Membranes were incubated at $4^{\circ} \mathrm{C}$ overnight with rabbit polyclonal antibodies against the intracellular part of rat nephrin (1034), ${ }^{19}$ podocin (Sigma), Nck1 (Abcam), and Nck2 (Abcam), and with a monoclonal antibody against $\alpha$-tubulin (Sigma) diluted in Odyssey blocking buffer in PBS supplemented with $0.1 \%$ Tween-20 (1:1). The following day, membranes were washed with $0.2 \%$ Tween-20 in PBS followed by a 1-hour incubation with anti-rabbit Alexa Fluor 680 (Molecular Probes, Eugene, OR) or anti-mouse Alexa Fluor 800 diluted 1:1 with Odyssey blocking buffer and PBS supplemented with $0.1 \%$ Tween-20 and $0.01 \%$ SDS. After repeated washes with PBS containing $0.2 \%$ Tween-20, the signal was detected using the Odyssey infrared imaging system (LI-COR Biosciences GmbH, Bad Homburg, Germany).

The relative expression levels were calculated by comparing the targets expression to the expression of control monoclonal antibody against $\alpha$-tubulin (Sigma).

\section{Data Analysis}

The results are presented as means \pm SD. Statistical analyzes were performed using SPSS for Windows 12.01
(SPSS Inc., Chicago, IL). Analyzes were performed using one-way analysis of variance (analysis of variance). When statistically significant differences $(P<0.05)$ were found, posthoc comparisons were performed using the least significant difference test (LSD) and Student's t-test.

\section{Results}

\section{A Transgenic Mouse Line with Podocyte-Specific Doxycycline-Inducible Nephrin Expression}

As a first step in the generation of a mouse model in which nephrin expression can be switched on and off, a podocyte-specific doxycycline inducible rat nephrin transgenic mouse line was generated. The inducibility of the expression of the transgene (Figure 1A) was tested in the human embryonic kidney cell line A293. Transgene expression was tightly regulated by doxycycline (data not shown). The construct was injected into FVB/N mouse oocytes. Ten out of 90 pups born carried the transgene, as detected by PCR. With 8 out of 10 rNeph founders a mouse line could be established on ICR background. The F1 offspring were fertile and appeared normal, with normal body weight compared with wild-type controls.

After 2 weeks of administration of $0.2 \mathrm{mg} / \mathrm{ml}$ doxycycline to 8- to 10-week-old male mice, the rNeph offspring from all founder lines remained healthy, with normal body weight and no abnormalities in kidney histology while no proteinuria was detected (data not shown). Nephrin mRNA expression was studied in the kidney cortex of rNeph mice at the age of 10 to 12 weeks by RT-PCR. The expression of rat specific nephrin mRNA was detected in the offspring of five out of seven founders (Figure 1B). One rNeph transgenic founder-line (86A) was selected for further characterization, because in that line the level of rat nephrin transgene expression was similar to endogenous nephrin expression (Figure 1B).

In 10- to 12-week-old offspring of the 86A founder-line, rat nephrin mRNA expression was firmly regulated by the administration of doxycycline and only detectable in the kidney cortex (Figure 1C). The transgenic rat nephrin expression was not detected in extra-renal tissues including brain, testis, pancreas, heart, lung, liver, and spleen (data not shown). Doxycycline induced expression of the rat nephrin transgene neither altered the expression pattern of the endogenous mouse nephrin gene in the kidney cortex, nor did it significantly alter the expression of the following genes expressed in podocytes: podocin, synaptopodin, CD2AP, FAT1, Fyn, Nck1, Nck2 and WT1 (Figure 1C). The unaltered RNA expression data could be confirmed on the protein level by immunofluorescent staining (see Supplemental Figure 1 at http://ajp.amjpathol.org). We therefore conclude that induction of a rat nephrin did not alter the expression of nephrin associated proteins in the adult mouse.

We also analyzed the mRNA expression of the rNeph transgene in the developing kidneys obtained from E11 and E14 embryos of doxycycline-treated mothers. Transgenic rat nephrin mRNA is already expressed at E11. 


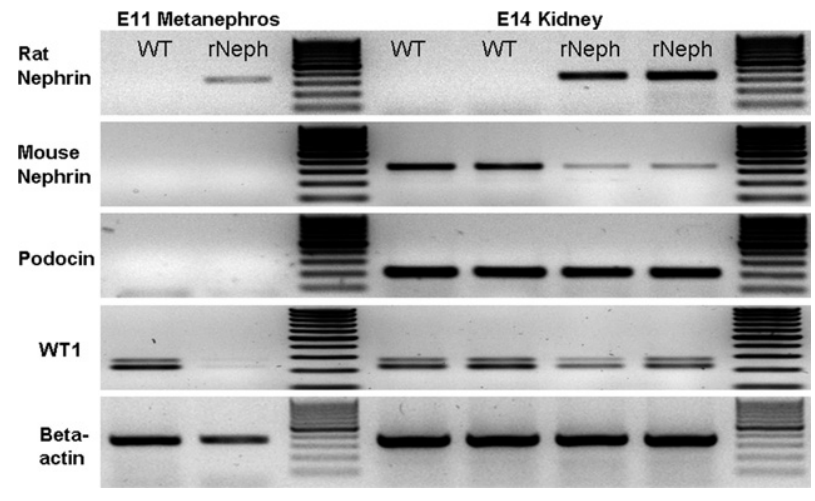

Figure 2. Expressions of rat nephrin, mouse nephrin, podocin, and WT1 mRNAs analyzed by RT-PCR. Total RNA was isolated from the kidneys of E11 and E14 wild-type (WT) and rNeph embryos collected from pregnant rNeph transgenic mouse line females with $2.0 \mathrm{mg} / \mathrm{ml}$ doxycycline in the drinking water. The primers used are listed in Table 2. Similar results were obtained with three independent experiments with three mice in each genotype.

Although in wild-type mice WT1, a transcription factor that controls nephrin expression is active at that time point, the endogenous mouse nephrin gene is still silent. Too early rat nephrin mRNA expression was associated with silencing of WT1 mRNA expression at E11 (Figure 2; left panel). At E14, the mRNA expression of the rat nephrin transgene was similar to the mRNA level of endogenous $\mathrm{mNeph}$ in wild-type littermates. In contrast, the expression of endogenous mNeph was dramatically decreased in rNeph mice while the expression of WT1 was only slightly decreased (Figure 2; right panel). However, the phenotype of adult rNeph mouse kidneys remained normal as can be noticed from the results of $\mathrm{rNeph} / \mathrm{mNeph}^{+/+}$mice, shown later in the rescue experiment. Therefore, it can be concluded that rNeph expression, starting too early during embryonic development, does not interfere with normal kidney development and with kidney function in 1- and 6-week-old rNeph mice, when endogenous nephrin expression is still present.

\section{Inducible Rat Nephrin Transgene Expression in Podocytes Rescues Nephrin-Deficient Mice from Perinatal Death}

As a next step in the generation of a mouse model in which nephrin expression can be switched on and off, the podocyte-specific inducible rat nephrin (rNeph) transgenic mouse line was crossed with a nephrin $\mathrm{KO}$ mouse line $\left(\mathrm{mNeph}^{-1-}\right) .^{9}$ While the large majority of conventional nephrin $\mathrm{KO}\left(\mathrm{mNeph}^{-1-}\right)$ mice die in utero and a small minority within a few days after birth, ${ }^{9}$ cross-breeding of $\mathrm{rNeph} / \mathrm{mNeph}^{+/-}$mice in the presence of doxycycline resulted in 14 (10 males and 4 females) out of 72 F2 pups $(20 \%)$ deficient for the endogenous nephrin gene but carrying the rat nephrin transgene ( $\left.\mathrm{rNeph} / \mathrm{mNeph}^{-/-}\right)$, which were all alive after 1 week of age. Three male offspring from each genotype were sacrificed at the age of 1 week for further analyzes.

The expression of endogenous mouse nephrin mRNA was absent in the kidneys of rescued $\mathrm{rNeph} / \mathrm{mNeph}^{-1-}$ littermates as expected, and normal in all other geno-
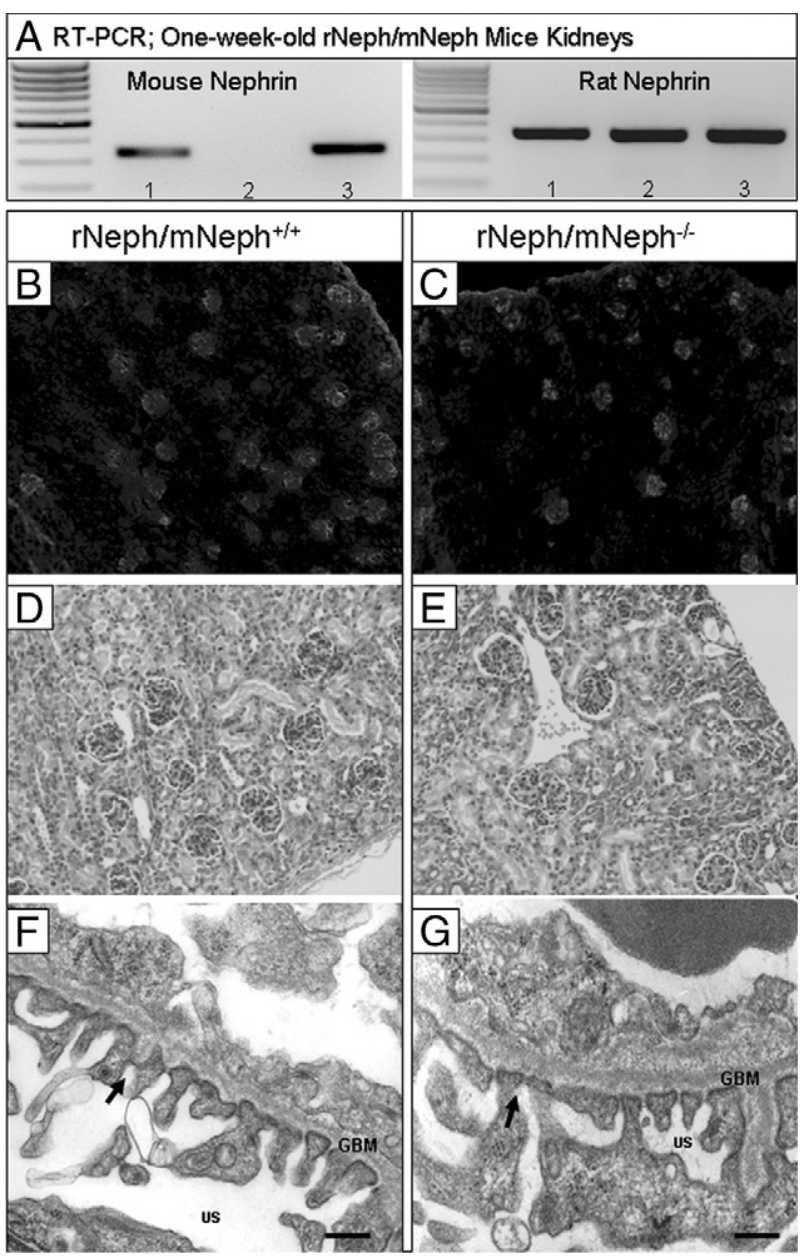

Figure 3. Expression of transgenic rat nephrin in podocytes rescues conventional nephrin KO mice from perinatal lethality with normal kidney and podocyte morphology at the age of 1 week. A: Mouse- and rat-specific nephrin mRNA expressions in $\mathrm{rNeph} / \mathrm{mNeph}$ mice kidney cortex at the age of 1 week, as analyzed by RT-PCR. Genotypes are marked 1) rNeph $\mathrm{mNeph}^{+/+}$, (2) $\mathrm{rNeph} / \mathrm{mNeph}^{-/-}$and (3) $\mathrm{rNeph} / \mathrm{mNeph}^{+/-}$. B and $\mathbf{C}$ Normal nephrin protein expression and localization in $\mathrm{rNeph} / \mathrm{mNeph}^{+/+}$ and $\mathrm{rNeph} / \mathrm{mNeph}^{-/-}$mice at the age of 1 week analyzed by immunofluorescent microscopy of frozen kidney sections (magnification $\times 100$ ). D and E: Kidney histology in $\mathrm{rNeph} / \mathrm{mNeph}^{+/+}$and $\mathrm{rNeph} / \mathrm{mNeph}^{-/-}$mice at the age of 1 week analyzed by H\&E staining of paraffin-embedded kidney sections ( $\times 200$ magnification). F and $\mathbf{G}$ : Electron microscopy shows relatively normal podocyte fine structures and well-preserved slit diaphragm structures in kidneys of $\mathrm{rNeph} / \mathrm{mNeph}^{+/+}$and $\mathrm{rNeph} / \mathrm{mNeph}^{-/-}$mice Arrows indicate existing slit diaphragms (SDs). Glomerular basement membrane (GBM); urinary space (US). Scale bars $=200 \mathrm{~nm}$.

types, as determined by RT-PCR (Figure 3A). The expression of the rat nephrin mRNA in the kidneys was similar in all genotypes and its level was comparable with the endogenous mouse nephrin expression in rNeph/ $\mathrm{mNeph}^{+/+}$mice (Figure 3A). No alterations were observed in the mRNA expression of podocin, synaptopodin, CD2AP, FAT1, Fyn, Nck1, Nck2 and WT1 (see Supplemental Figure 2 at http://ajp.amjpathol.org).

Immunofluorescent microscopy of kidney cortex showed that nephrin was similarly expressed in all glomeruli and localized apparently to the podocytes in all genotypes at the age of 1 week (Figure 3B and $\mathrm{C}$ ). Immunostaining with podocin-, Fyn-, Nck1-, Nck2-, and WT1-specific antibodies did not reveal differences in 
expression and localization of these proteins in 1-weekold $\mathrm{rNeph} / \mathrm{mNeph}^{-1-}$ mice, as compared with rNeph/ $\mathrm{mNeph}^{+/+}$controls (see Supplemental Figure 3 at http://ajp.amjpathol.org).

The histology of 1-week-old $\mathrm{rNeph} / \mathrm{mNeph}^{-1-}$ mouse kidneys was normal, as compared with the rNeph/ $\mathrm{mNeph}^{+/+}$littermate controls (Figure 3, D and E). Electron microscopy analysis showed that podocyte morphology and slit diaphragm fine structures were close to normal in 1-week-old $\mathrm{rNeph} / \mathrm{mNeph}^{-1-}$ mice, because only mild foot process effacement was noticed in a few podocytes of these mice (Figure 3, F and G). From these results, it can be concluded that the doxycycline-induced transgene expression of rat nephrin rescued mice deficient for endogenous nephrin from perinatal death without gross abnormalities in organogenesis or organ structure of the kidney and with normal morphology of podocytes and normal architecture of the slit diaphragm.

\section{Rescued Rat Nephrin Transgenic Mice Deficient for Endogenous Nephrin Develop a Severe Renal Phenotype}

All rescued $\mathrm{rNeph} / \mathrm{mNeph}^{-1-}$ mice were smaller and had lower body weight compared with littermate controls ( $\mathrm{Ta}$ ble 1). Two rNeph/mNeph ${ }^{-1-}$ females died between the age of 7 and 14 days. All rNeph/mNeph ${ }^{-1-}$ pups suffered from severe proteinuria $(\geq 3.0 \mathrm{~g} / \mathrm{L})$ at the age of 3 weeks, which was the earliest possible time point to collect urine after weaning (Table 1). Three males died between the age of 38 and 40 days and showed severe proteinuria $(\geq 3.0 \mathrm{~g} / \mathrm{L})$ with histological changes in their kidneys including glomerular changes and tubular dilatations with proteinaceous material (data not shown). The remaining $55 \%$ of the $\mathrm{rNeph} / \mathrm{mNeph}^{-1-}$ offspring (five males and one female) survived until the age of 6 weeks, when they were sacrificed for further analyses.

The kidneys from 6-week-old rescued rNeph/ $\mathrm{mNeph}^{-1-}$ mice showed striking histological abnormalities known to be associated with proteinuria, eg, tubular dilatations, as compared with the kidneys of agematched control $\mathrm{rNeph} / \mathrm{mNeph}^{+/+}$littermates (Figure 4, $A$ and $B$ ). With electron microscopy, a variety of morphological changes such as a foot process effacement, mesangial expansion, and glomerular basement membrane thickening (Figure 4, D and F) were observed in podocytes of rNeph/mNeph ${ }^{-1-}$ mice, as compared with the podocytes of age-matched $\mathrm{rNeph} / \mathrm{mNeph}^{+/+}$littermate controls (Figure 4, C and E). Despite of foot process effacement, slit diaphragm structures were still observed in rNeph/ $\mathrm{mNeph}^{-1-}$ mice at both ages analyzed (Figures $3 \mathrm{G}$ and 4F; Arrows). These results show that the doxycycline-induced expression of rat nephrin is sufficient for the development of slit diaphragm structures because slit diaphragms are completely absent in nephrin $\mathrm{KO}$ mice already at time of birth. ${ }^{8,9}$

The expression of the induced rat nephrin mRNA in the $\mathrm{KO}$ mouse kidneys was similar in all genotypes and its level was comparable with the endogenous mouse nephrin expression in $\mathrm{rNeph} / \mathrm{mNeph}^{+/+}$control mice at age of 6 weeks (Figure 5 A). In addition, immunofluorescent

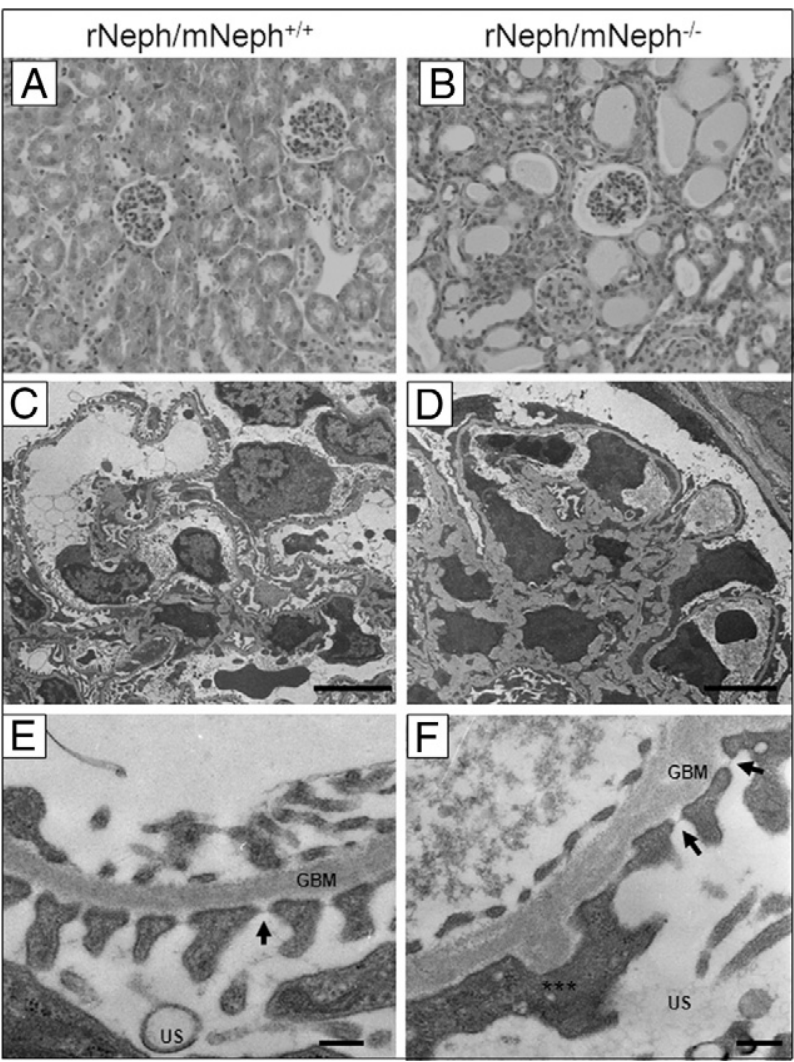

Figure 4. The kidneys from 6 -week-old rescued $\mathrm{rNeph} / \mathrm{mNeph}^{-/-}$mice showed proteinuria-associated histological abnormalities and a variety of podocyte damage. $\mathbf{A}$ and $\mathbf{B}$ : H\&E staining of paraffin-embedded kidney sections from $\mathrm{rNeph} / \mathrm{mNeph}^{+/+}$and $\mathrm{rNeph} / \mathrm{mNeph}^{-/-}$mice (magnification $\times 200)$. C-F: Electron microscopy showed a variety of morphological changes such as a foot process effacement, mesangial expansion, and glomerular basement membrane thickening in podocytes of the rescued rNeph/ $\mathrm{mNeph}^{-1-}$ mice, as compared with $\mathrm{rNeph} / \mathrm{mNeph}^{+/+}$littermate controls. Despite of foot process effacement, slit diaphragm structures were still observed in $\mathrm{rNeph} / \mathrm{mNeph}^{-1-}$ mice $(\mathbf{F})$. Arrows indicate still existing slit diaphragms (SDs). Asterisks indicate area were partial foot process effacement can be seen. Glomerular basement membrane (GBM), urinary space (US). Scale bars: $5 \mu \mathrm{m}(\mathbf{C}$ and $\mathbf{D}) ; 200 \mathrm{~nm}(\mathbf{E}$ and $\mathbf{F})$.

microscopy showed that nephrin protein was normally expressed in rNeph/mNeph ${ }^{-1-}$ mouse glomeruli and localized apparently onto the cell surface of the podocytes (Figure 5, B and C). Immunogold electron microscopy with nephrin antibody showed that in rescued rNeph/ $\mathrm{mNeph}^{-1-}$ mice at age of 6 weeks, the rat nephrin is localized in the same spots in the foot processes of the podocytes, in the slit diaphragm domain, as the endogenous nephrin in the control genotype (Figure 5, D and E). Nephrin localization was analyzed in the kidney of one control rNeph/mNeph ${ }^{+/+}$mouse and one rescued rNeph/ $\mathrm{mNeph}^{-1-}$ mouse. The expression and localization of nephrin protein in slit diaphragm area and in podocyte cytoplasm was similar in both genotypes (Figure 5F). However, in the kidneys of rescued mice the amount of nephrin protein in the membrane areas outside the slit diaphragm area was increased and this difference was statistically significant $(P<0.05$; Figure $5 \mathrm{~F})$.

These results show that rat nephrin transgene expression during embryonic development and thereafter can rescue mice, deficient for endogenous nephrin, from the perinatal death. However, despite normal transgenic 


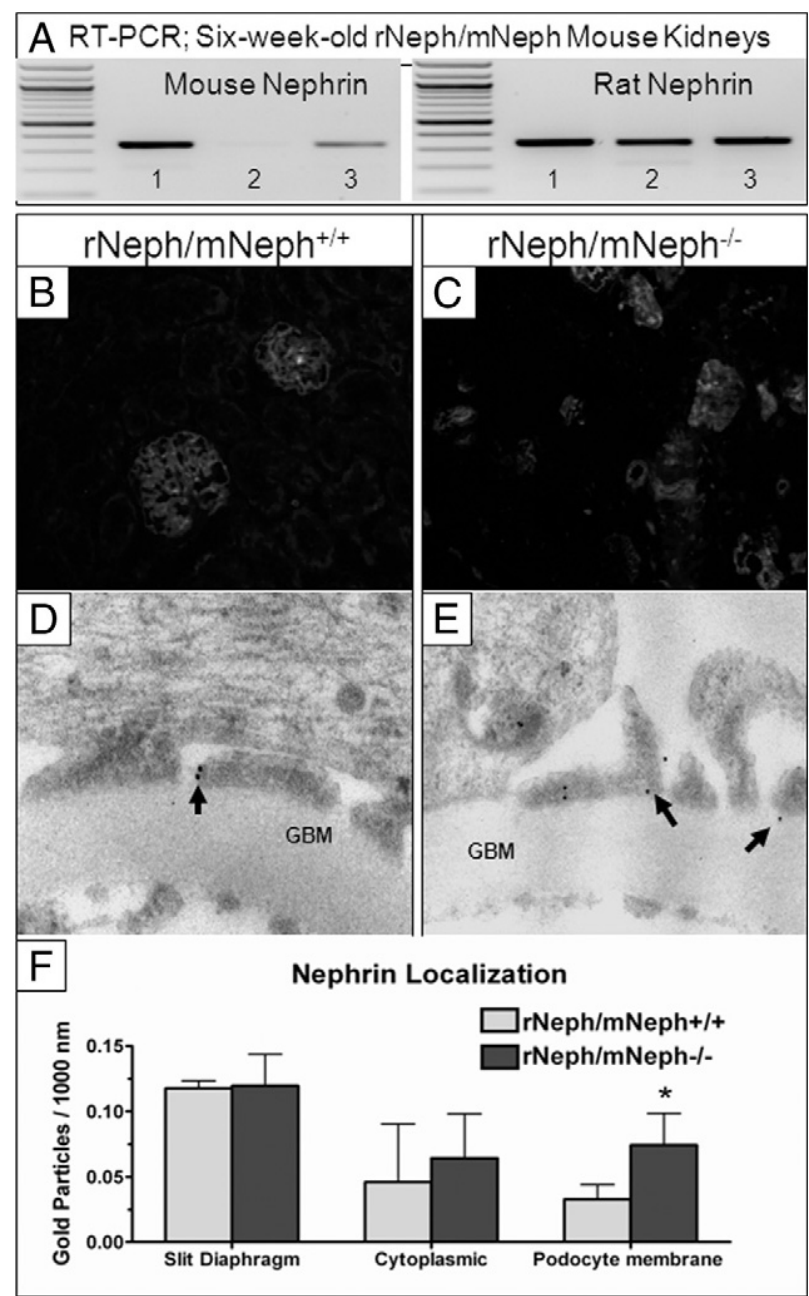

Figure 5. The expression and localization of the rat nephrin mRNA and protein in the kidneys was similar in rescued $\mathrm{rNeph} / \mathrm{mNeph}^{-/-}$mice, as compared with control littermates at the age of 6 weeks. A: Mouse- and rat-specific nephrin mRNA expressions in $\mathrm{rNeph} / \mathrm{mNeph}$ mice kidney cortex at the age of 6 weeks, as analyzed by RT-PCR. Genotypes are marked 1) $\mathrm{rNeph} / \mathrm{mNeph}^{+/+}$, (2) rNeph/ $\mathrm{mNeph}^{-/-}$, and (3) $\mathrm{rNeph} / \mathrm{mNeph}^{+/-}$. B and C: Nephrin protein expression and localization in $\mathrm{rNeph} / \mathrm{mNeph}^{+/+}$and $\mathrm{rNeph} / \mathrm{mNeph}^{-/-}$mice at the age of 6 weeks, analyzed by immunofluorescent microscopy of frozen kidney sections (magnification $\times 200$ ). D and E: Immunogold electron microscopy shows normal nephrin localization in the slit diaphragm area in rescued $\mathrm{rNeph} / \mathrm{mNeph}^{-1}$ mice, when compared with control $\mathrm{rNeph} / \mathrm{mNeph}^{+/+}$mice. Arrows indicate nephrin protein localization. Glomerular basement membrane (GBM). F: Nephrin localization was unaltered in slit diaphragm area and in podocyte cytoplasm in the rescued $\mathrm{rNeph} / \mathrm{mNeph}^{-/-}$mouse, as compared with the control $\mathrm{rNeph}$ $\mathrm{mNeph}^{+/+}$mouse. However, more nephrin protein was found in the podocyte membrane outside the slit diaphragm area from the rescued mouse and this increase was statistically significant $\left({ }^{*} P<0.05\right)$. The number of gold particles were counted manually and expressed as the number/1000 nm length of podocyte membrane. Student's $t$-test was used for statistical analysis.

nephrin expression and its correct localization in the rescued mice, abnormalities were developing after birth in the podocytes associated with emerging proteinuria.

\section{Altered Gene Expression in the Rescued Mouse Kidneys}

Gene expression analysis by RT-PCR showed that expression of podocin and Nck2 mRNA was clearly decreased in 6-week-old $\mathrm{rNeph} / \mathrm{mNeph}^{-1-}$ mice, as compared with the expression levels of these genes in the

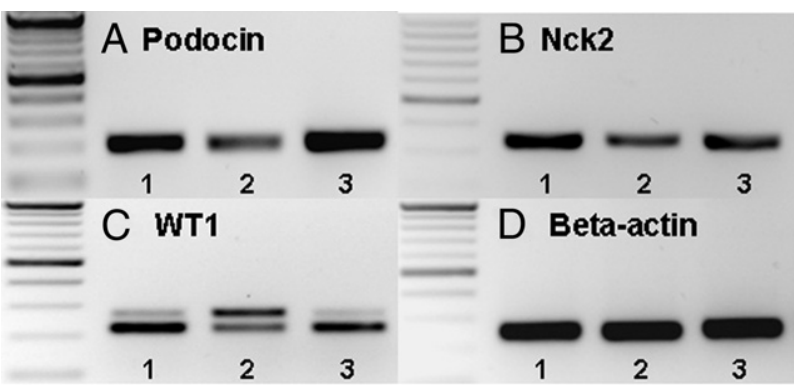

Figure 6. Changes expression of podocin, Nck2, and WT1 mRNAs in 6-week-old rescued $\mathrm{rNeph} / \mathrm{mNeph}^{-/-}$mice. RT-PCR was performed with total RNA isolated from kidney cortex at the age of 6 weeks. Genotypes are marked: 1) $\mathrm{rNeph} / \mathrm{mNeph}^{+/+}$, 2) $\mathrm{rNeph} / \mathrm{mNeph}^{-/-}$, and 3) $\mathrm{rNeph} /$ $\mathrm{mNeph}^{+/-}$. A and B: Podocin and Nck 2 expression was decreased in rescued $\mathrm{rNeph} / \mathrm{mNeph}^{-/-}$mice kidneys. C: WT1 expression was analyzed using a primer set designed to amplify different splicing forms with or without exon 5 . The results showed an increase in the exon 5 containing mRNA variant in rescued $\mathrm{rNeph} / \mathrm{mNeph}^{-1-}$ mice, as compared with the control genotypes. D: $\beta$-actin expression was similar in all genotypes. Primers and size of the products are listed in Table 2. Similar results were obtained in three independent experiments with three mice of each genotype.

rNeph/mNeph ${ }^{+/+}$controls (Figure 6A, B, D). Furthermore, the ratio between different splice variants of WT1 mRNA was markedly altered in rescued $\mathrm{rNeph} / \mathrm{mNeph}{ }^{-1-}$ mice (Figure 6C). Using a primer set designed to amplify different splicing forms with or without exon 5 , an increase in the exon 5 containing mRNA variant was observed in rescued $\mathrm{rNeph} / \mathrm{mNeph}^{-1-}$ mice, as compared with WT1 mRNA species in the control genotypes (Figure 6C). In contrast no alterations in the mRNA expression of synaptopodin, CD2AP, FAT1, Fyn, Nck1 were observed (see Supplemental Figure 4 at http://ajp.amjpathol.org).

Immunostaining, applying double-staining with synaptopodin antibody as a reference, revealed quantitative and qualitative differences in 6-week-old rNeph/ $\mathrm{mNeph}^{-1-}$ mice, as compared with control rNeph/ $\mathrm{mNeph}^{+/+}$mice kidneys (Figure 7, 8 and 9). The podocin protein was markedly decreased (Figure 7) confirming the mRNA data in 6-week-old $\mathrm{rNeph} / \mathrm{mNeph}^{-1-}$ mice. The Fyn protein levels in the area close to the podocyte foot processes and slit diaphragm were increased (Figure 7). The Nck2 protein, which co-localized with synaptopodin in $\mathrm{rNeph} / \mathrm{mNeph}^{+/+}$mice while Nck1 did not, was absent in $\mathrm{rNeph} / \mathrm{mNeph}^{-1-}$ mice (Figure 8). Surprisingly, WT1 expression was absent in the nucleus of the podocytes in 6-week-old rescued $\mathrm{rNeph} / \mathrm{mNeph}{ }^{-1-}$ mice while present in $\mathrm{rNeph} / \mathrm{mNeph}^{+/+}$mice (Figure 9A).

Although localization and expression level of nephrin protein remained close to normal, 6-week-old rNeph/ $\mathrm{mNeph}^{-1-}$ mice showed an increased level of the phosphorylated nephrin form ( $\sim 180 \mathrm{kDa})$ compared with the other genotypes as determined by immunoblotting (Figure 9B). On SDS-polyacrylamide gel electrophoresis, rat nephrin runs as a doublet, presumably because of differential glycosylation, and it has been shown that the upper band of $\sim 180 \mathrm{kDa}$ corresponds with the phosphorylated nephrin. ${ }^{22}$ Quantitative immunoblotting experiments confirmed the RT-PCR and immunofluorescent microscopic findings showing decrease of podocin and Nck2 protein expression level $(P<0.001)$ while Nck1 remained unchanged (Figure 9C). 


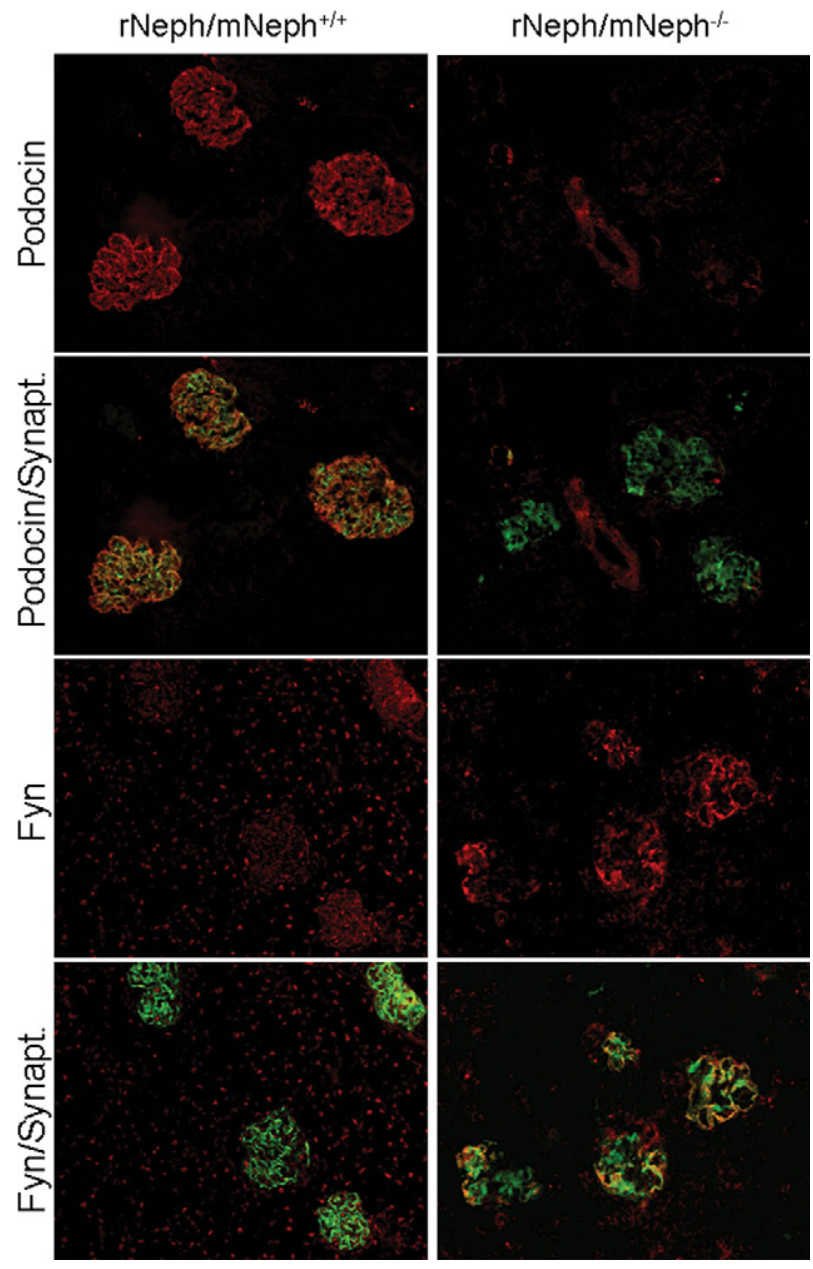

Figure 7. Changed podocin and Fyn protein expression in 6-week-old rescued $\mathrm{rNeph} / \mathrm{mNeph}^{-1-}$ mice. Immunofluorescent double-staining of frozen kidney sections from $\mathrm{rNeph} / \mathrm{mNeph}^{+/+}$(left panel) and $\mathrm{rNeph} / \mathrm{mNeph}{ }^{-}$ (right panel) mice with podocin-, Fyn-, and synaptopodin-specific antibodies showed that podocin protein is markedly decreased in the rescued mice, as compared with control mouse kidneys (two upper rows). Instead, the Fyn protein levels in the area close to the podocyte foot processes and slit diaphragm were increased in the rescued mice (two lowest rows). Magnification: $\times 200$.

Taken together, these findings indicate that doxycycline treated $\mathrm{rNeph} / \mathrm{mNeph}^{-1-}$ mice develop a kidney disease before adulthood, with substantial alterations in the expression of proteins associated with (a) the regulation of expression of nephrin (WT1), (b) phosphorylation of nephrin protein (Fyn), and (c) intracellular signaling of nephrin (podocin and Nck2).

\section{Podocyte Specific Rescue of Nephrin Results in Severe Extra-Renal Phenotypes}

At the age of 5 to 6 weeks, all rNeph/mNeph ${ }^{-1-}$ male mice were smaller in size, infertile, the size of their penis was smaller, testicles had not descended, and seminal vesicle formation was severely impaired (Figure 10, A-F). Light microscopy of H\&E-stained sections showed striking differences in the morphology of the testes included decreased numbers of Leydig cells and spermatids and absence of the lumen of the seminiferous tubules of the testis (Figure 11, A and B).
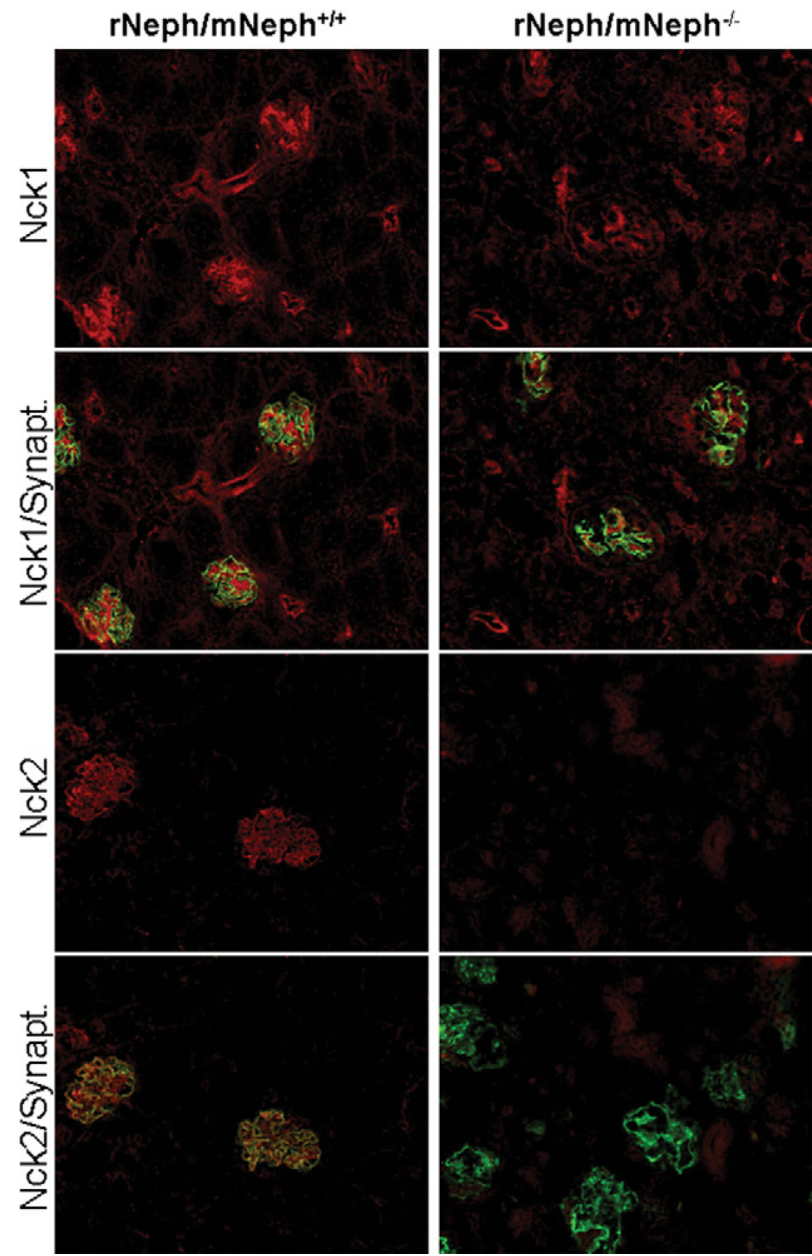

Figure 8. Absence of Nck2 protein expression in 6-week-old rescued rNeph mNeph ${ }^{-/-}$mice. Immunofluorescent staining of frozen kidney sections from $\mathrm{rNeph} / \mathrm{mNeph}^{+/+}$(left panel) and $\mathrm{rNeph} / \mathrm{mNeph}^{-/}$(right panel) mouse kidneys with Nck1-, Nck2-, and synaptopodin-specific antibodies showed slit diaphragm-specific staining and co-localization of Nck2 protein with synaptopodin in $\mathrm{rNeph} / \mathrm{mNeph}^{+/+}$mice (two lower rows). The Nck1 protein shows some glomerular, but also strong tubular staining (two upper rows). The Nck1 protein expression levels remain closely similar between genotypes, but Nck2 protein was completely absent in $\mathrm{rNeph} / \mathrm{mNeph}^{-/-}$mice. Magnification: $\times 200$.

At the age of 5 weeks, the rescued $\mathrm{rNeph} / \mathrm{mNeph}^{-1-}$ mice showed a significant changes in behavior compared with control rNeph/mNeph ${ }^{+/-}$and $\mathrm{rNeph} / \mathrm{mNeph}^{+/+}$genotypes. Particularly, the behavioral evaluations in the viewing jar showed substantially decreased spontaneous activity in $\mathrm{rNeph} / \mathrm{mNeph}^{-1-}$ mice, as compared with other genotypes $(P<0.05)$. After transfer to an open arena, elevated pelvic and tail dragging during locomotion was observed in all $\mathrm{rNeph} / \mathrm{mNeph}^{-1-}$ mice $(P<0.001)$. Rescued $\mathrm{rNeph} / \mathrm{mNeph}^{-1-}$ mice also had reduced locomotor activity in the novel environment $(P<0.05)$. These results are summarized in Table 3 . Light microscopy of H\&E-stained sections showed loss of polarization of Purkinje cells of the cerebellum in all $\mathrm{rNeph} / \mathrm{mNeph}^{-1-}$ mice at the age of 6 weeks when compared with age-matched rNeph/mNeph ${ }^{+/+}$littermates (Figure 11, C-D). Light microscopy did not reveal abnormalities in other parts of brain or in other organs including liver, lung, spleen, and heart (data not shown). 


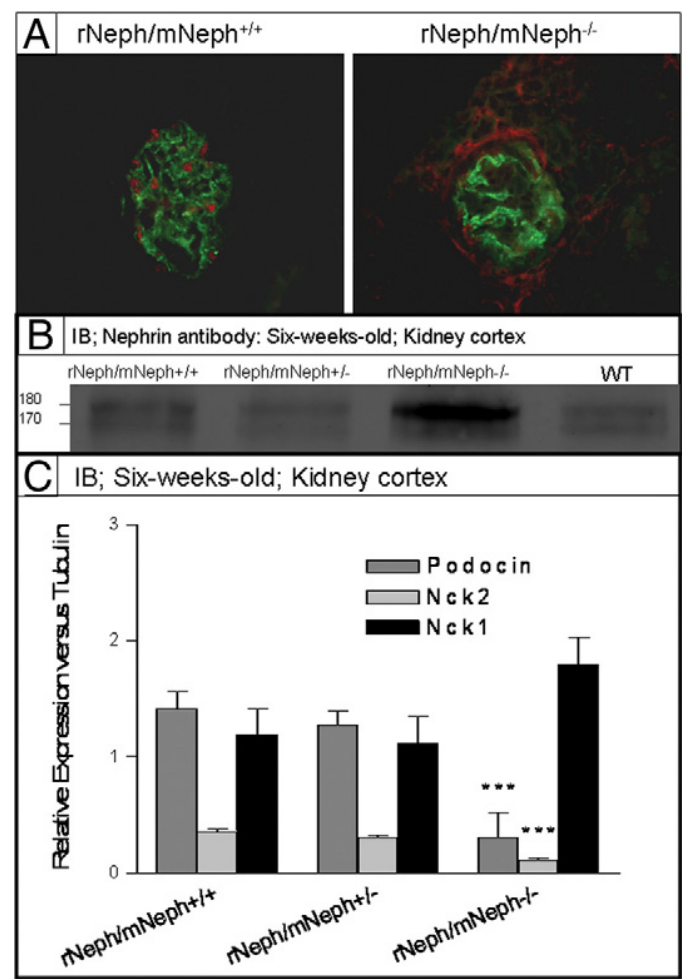

Figure 9. A: Immunofluorescent staining with WT1 and synaptopodin specific antibodies on frozen kidney sections from 6-week-old rNeph/ $\mathrm{mNeph}^{+/+}$, and rescued $\mathrm{rNeph} / \mathrm{mNeph}^{-/-}$mice. Surprisingly, WT1 expression was absent in the nucleus of 6 -week-old rescued $\mathrm{rNeph} / \mathrm{mNeph}^{-}$ mice podocytes when still present in age-matched control kidneys. Magnification: $\times 200$. B: Immunoblotting from kidney cortex lysate with nephrin antibody showed an increased level of the phosphorylated nephrin form ( $\sim 180 \mathrm{kDa}) \mathrm{rNeph} / \mathrm{mNeph}^{-1-}$ mice, as compared with the other genotypes (Figure 9B). C: Quantitative immunoblotting experiments verified RT-PCR and immunofluorescent microscopic findings that expression level of podocin and Nck2 has been decreased $\left({ }^{* * *} P<0.001\right)$ and Nck1 unchanged in rescued mice as compared with control $\mathrm{rNeph} / \mathrm{mNeph}^{+/+}$littermates.

\section{Discussion}

In mouse and man, nephrin is expressed in the podocytes of the kidney, ${ }^{23-25}$ in brain, ${ }^{8}$ in testis, ${ }^{26}$ in the $\beta$-cells of the Islets of Langerhans in the pancreas, ${ }^{8,27,28}$ in placenta, ${ }^{29}$ and in lymphoid tissues. ${ }^{30}$ Kidney transplantation within the first year can safe the life of nephrindeficient children. ${ }^{31}$ These children are free from any symptoms in other nephrin-expressing tissues ${ }^{32,33}$ except for an increase in muscular dystonia and mild ataxia in some cases. ${ }^{34}$ In the present study, it is shown that induction of transgenic rat nephrin expression early during embryonic development (E11) exclusively in the podocytes rescues nephrin deficient mice from perinatal death. This suggests that also in the mouse the lethal phenotype associated with nephrin deficiency is primarily caused by loss of kidney function.

However, the rescued ( $\mathrm{rNeph} / \mathrm{mNeph}^{-1-}$ ) mice were smaller with lower body weight at birth and before reaching adulthood they developed severe proteinuria. Light microscopy of kidney sections from 6-week-old rescued mice showed abnormalities including dilatations in the tubular profiles. Detailed analysis by electron microscopy showed that at the age of 6 weeks abnormalities in the podocyte fine structures developed, including partial foot
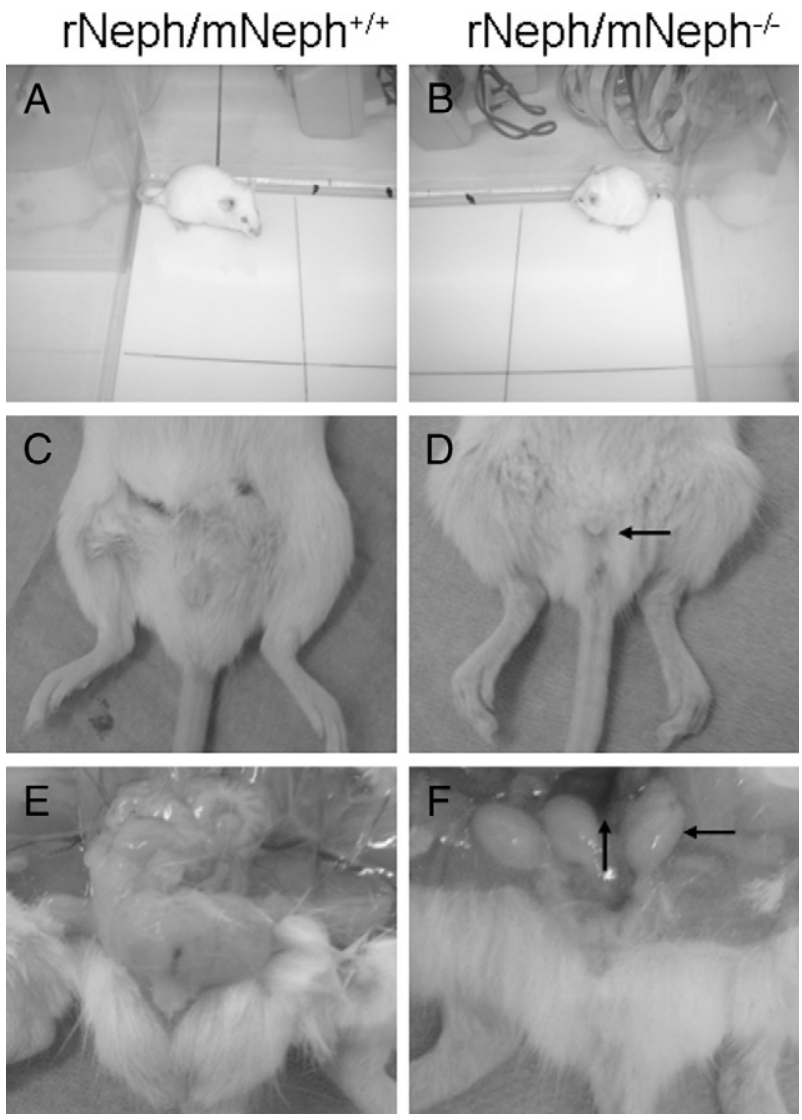

Figure 10. All rescued $\mathrm{rNeph} / \mathrm{mNeph}^{-/-}$male mice were smaller in size, infertile, and their genitals showed anatomical malformations at the age of 5 to 6 weeks. $\mathbf{A}$ and $\mathbf{B}$ show the differences in body size. $\mathbf{C}$ and $\mathbf{D}$ show the smaller size of the male genitals of $\mathrm{rNeph} / \mathrm{mNeph}^{-/-}$mice. $\mathbf{E}$ and $\mathbf{F}$ show that testicles had not descended and seminal vesicle formation was severely impaired in $\mathrm{rNeph} / \mathrm{mNeph}^{-1-}$ males. These changes have been highlighted with arrows in $\mathbf{D}$ and $\mathbf{F}$.

process effacement and glomerular basement membrane thickening. However, morphologically normal-appearing slit diaphragms were still present. Importantly, slit diaphragm structures were never found in conventional nephrin-deficient newborns and partial foot process effacement was observed already in conventional nephrin heterozygote $\mathrm{KO}$ mice. ${ }^{9}$ These severe kidney and podocyte abnormalities were not observed in rescued 1-week-old rNeph/mNeph ${ }^{-1-}$ mice despite of mild foot prosess effacement in a few podocytes. Since control $\mathrm{rNeph} / \mathrm{mNeph}^{+/+}$mice did not show any abnormalities in the kidney structure and function, we concluded that the progressing morphological changes in the rescued $\mathrm{rNeph} / \mathrm{mNeph}^{-1-}$ mice are due to incomplete complementation of endogenous nephrin deficiency. There are several explanations why the expression of the rat nephrin transgene results only in partial complementation in rescued nephrin $\mathrm{KO}$ mice, which will be discussed below.

Transgenic rat nephrin expression started already on E11, while endogenous nephrin expression starts at about day E13 in wild-type mouse kidneys. ${ }^{8}$ Transgenic rat nephrin expression at E11 was associated with decreased expression of the transcription factor WT1, which controls the expression of several genes (including nephrin) active in podocytes during glomerulogenesis. ${ }^{35}$ This 


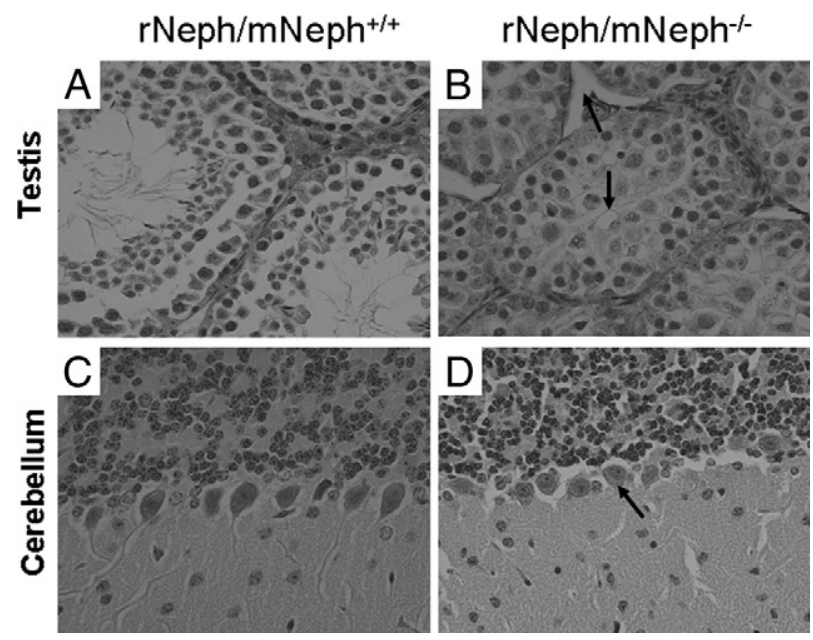

Figure 11. Histological experiments by H\&E staining and light microscopy revealed striking morphological differences in testis and cerebellum of all rescued $\mathrm{rNeph} / \mathrm{mNeph}^{-1-}$ male mice at the age of 6 weeks. These histological changes included (marked as arrows): $\mathbf{A}$ and B: Decreased number of Leydig cells and spermatids and absence of the lumen of the seminiferous tubules of the testis. $\mathbf{C}$ and $\mathbf{D}$ : The loss of polarization of the Purkinje cells in the cerebellum. Magnification: $\times 200$.

may indicate a possible premature activation of downstream feedback mechanisms. In rNeph/mNeph ${ }^{+/+}$embryos expression of endogenous nephrin started at the expected day E14, but the level was substantially decreased, suggesting that the expression of endogenous nephrin was influenced by transgenic rat nephrin expression. WT1 mRNA expression appeared to be slightly decreased in E14 $\mathrm{rNeph} / \mathrm{mNeph}^{+/+}$embryos, as compared with wild-type controls. These findings suggest that rat nephrin expression may have an effect on the expression of WT1 and that the decreased endogenous nephrin expression can be an indirect effect of decreased WT1 expression. However, in the presence of endogenous nephrin, the transgenic rat nephrin expression did not have any effect on the development and functioning of the adult kidney as shown in 6-week-old control $\mathrm{rNeph} / \mathrm{mNeph}{ }^{+/+}$mice. Therefore it is unlikely that too early onset of $r$ Nephrin expression is an important reason why the rescue is incomplete.

In 6-week-old rescued $\mathrm{rNeph} / \mathrm{mNeph}^{-1-}$ mice, changes in the nuclear localization of the WT1 protein and in the alternative splicing pattern of WT1 mRNA were found. A strong correlation between the presence of WT1 splice variants and nephrin expression has previously been demonstrated. ${ }^{36}$ In comparison with wild-type controls, nephrin expression is dramatically decreased in the kid- neys of mice that lack specifically the WT1(-KTS) splice variant, and reduced in animals deficient for the WT1(+KTS) splice variant. ${ }^{36}$ Here, we show that especially the expression level of the exon 5 containing WT1 splice variant was increased in 6-week-old rescued $\mathrm{rNeph} / \mathrm{mNeph}^{-1-}$ littermates, while there was no difference between the KTS variants. It has been shown that the different KTS splice variants have different nuclear localization and distinct functions during the organogenesis of the reproductive organs and nephron formation. ${ }^{37}$ It is tempting to speculate that the noticed changes in the nuclear location of WT1 protein are due to an altered exon 5 splicing of WT1 transcripts. The observed changes in the expression pattern and localization of the transcription factor WT1, a key molecule driving the differentiation of podocytes, together with striking changes in expression and localization of molecules associated with nephrin signaling (Fyn, Nck2) suggest that in the absence of endogenous nephrin, rat nephrin was not able to maintain the normal program of podocyte differentiation in the rescued rNeph/ $\mathrm{mNeph}^{-1-}$ mice after birth. It is of note that in the mouse both structural and functional development of the kidney still continues several weeks after birth in contrast to man, who is born with a fully developed kidney.

Although our results with RT-PCR, immunofluorescent staining, immunoblotting and immunogold electron microscopy suggest that the expression level and localization of the transgenic rat nephrin protein in all kidneys and in remaining slit diaphragms of the rescued mice was similar to the expression level and localization of endogenous nephrin in control genotypes, small differences in the critical cellular levels and localization of the nephrin protein cannot be excluded. Interestingly, as shown with immunogold electron microscopy, in the membrane areas outside the slit diaphragm area of podocytes from rescued mice the amount of nephrin protein was increased compared with the amount of nephrin in the membranes of podocytes from age-matched rNeph/mNeph ${ }^{+/+}$littermate controls. One explanation for this increase of nephrin is that nephrin remains in podocyte membranes after partial loss of slit diaphragm structures and foot process effacement. Similarly, an electron micrographic examination of kidneys from 4-day-old Nck ${ }^{-1-}$ pups showed complete fusion of foot processes while nephrin staining was unaltered even at the age of 10 days. ${ }^{38}$ Although nephrin is normally distinctly located at the filtration slit area, its presence at the apical plasma membrane of human podocytes is reported ${ }^{24}$ and confirmed in the mouse in an experimental model of glomerular diseases ${ }^{39}$.

Table 3. Summary of the Differences between the Genotypes in Primary Behavioral Screening at the Age of 5 Weeks

\begin{tabular}{|c|c|c|c|}
\hline \multicolumn{4}{|c|}{ Mean $\pm S D$ or number of mice exhibiting of the observed behavior } \\
\hline & $\begin{array}{c}\mathrm{rNeph} / \mathrm{mNeph}^{+/+} \\
n=3\end{array}$ & $\begin{array}{c}\mathrm{rNeph} / \mathrm{mNeph}^{+/-} \\
n=3\end{array}$ & $\begin{array}{c}\mathrm{rNeph} / \mathrm{mNeph}^{-/-} \\
n=5\end{array}$ \\
\hline Spontaneous activity & $2.33 \pm 0.57$ & $2.67 \pm 0.58$ & $1.20 \pm 0.45^{\star}$ \\
\hline Locomotor activity & $24.67 \pm 6.43$ & $23.67 \pm 7.57$ & $11.80 \pm 5.45^{\star}$ \\
\hline Elevated pelvic & 0 & 0 & $5^{\star \star \star}$ \\
\hline Dragging tail & 0 & 0 & $5^{\star * *}$ \\
\hline
\end{tabular}

\footnotetext{
Statistical significant differences after LSD test: ${ }^{*} P<0.05 ;{ }^{* * *} P<0.001$
} 
The differences between the mouse and rat nephrin protein may lead to inappropriate complementation. Fulllength rat nephrin cDNA was chosen as the coding sequence of the transgene because it shares high homology with mouse nephrin, but has minute differences in the coding sequence enabling distinction from mouse endogenous nephrin by RT-PCR in vivo. On phosphorylation by Src-family tyrosine kinases (eg, Fyn) three conserved tyrosine-based motifs (YDxV) in the cytoplasmic tail of nephrin can bind to the $\mathrm{SH} 2$ domain of the Nck adaptor proteins. ${ }^{38,40}$ After we had generated our rNeph transgenic mouse line, it was published that one of these three tyrosine motifs important for Nck binding in human (1176YDEV) and mouse (1191-YDEV), is not conserved in the rat nephrin sequence (1187-HDEV). ${ }^{10,38,40}$

Nephrin-Nck interaction that occurs after the phosphorylation of nephrin by the tyrosine kinase Fyn is important for podocyte foot process development and repair after filtration barrier injury. ${ }^{38,41}$ Very recently it has been shown that inducible deletion of Nck1 and 2 in the podocytes of adult mice results in the development of proteinuria and reduces phosphorylation levels of nephrin protein in adult mouse kidneys. ${ }^{42}$ These findings suggest that Nck proteins are also required to maintenance of fully differentiated podocytes. Furthermore, it has been reported that both nephrin tyrosine phosphorylation and nephrin-Nck interactions are reduced significantly in a rat model of podocyte injury and proteinuria. $^{22}$ Therefore, we analyzed on the one hand, the phosphorylation status of nephrin and on the other hand the expression of podocyte-specific proteins that are involved in nephrin phosphorylation and intracellular signaling. Immunoblotting showed an increased level of the phosphorylated nephrin form $(\sim 180 \mathrm{kDa})$ in rescued rNeph/ $\mathrm{mNeph}^{-1-}$ mice, as compared with the other genotypes. On SDS-polyacrylamide gel electrophoresis, rat nephrin runs as a doublet, presumable because of differential glycosylation and it has been shown that the upper band of $\sim 180 \mathrm{kDa}$ corresponds with phosphorylated nephrin. ${ }^{22}$ Immunofluorescent microscopy showed that in mouse podocytes Nck2 protein is present more prominently compared with Nck1. Interestingly, in the podocytes of 6-week-old, but not 1-week-old rNeph/mNeph ${ }^{-1-}$ mice, Nck2 protein expression was almost totally absent, while expression and localization of this protein did not change during the same time period in littermate controls. The observed changes in the expression pattern of key signaling molecules in rescued $\mathrm{rNeph} / \mathrm{mNeph}^{-1-}$ mice were associated with the onset and continuous increase of proteinuria after 3 and up to 6 weeks of age. These findings may indicate that due to the absence of one out of three tyrosine residues present in mouse and human nephrin, rat nephrin is not capable to mediate intracellular signaling in mouse podocytes resulting in loss of foot process integrity after birth in the rescued mice. It is tempting to speculate that the increased phosphorylation of the intracellular domain of nephrin by Fyn reflects the effort of the biological system to compensate for the decreased binding of rat nephrin to the mouse Nck adaptor proteins.

Both in mouse and man, nephrin deficiency results in a dramatic lethal phenotype preventing detailed analysis of the nephrin function in other organs. Therefore we performed behavioral screening with all rescued mice and control genotypes at age of 5 weeks when the overall condition of the rescued mice was still quite good. Our results showed that rescued mice have impaired spontaneous activity and impaired coordination in hind legs and tail resembling observations in some CNF patients with an increase in muscular dystonia and mild ataxia. ${ }^{34}$ Although the rescued males showed normal sexual activity, they were infertile. Our preliminary histological studies showed that both in cerebellum and in testis of 6-week-old rescued mice significant histological changes were manifest, when compared with control littermates. No mature spermatids were found in rescued males, explaining their infertility. The polarization of Purkinje cells was disrupted in rescued mice, which might explain the changes in the locomotor activity and coordination. In conclusion, these observations indicate that loss of nephrin expression in extra renal tissues have serious consequences for the development and function of those tissues. By using our rescued mouse model presented here the role of nephrin loss in extra-renal tissues can now be analyzed in more detail at a cellular and molecular level although secondary effects of severe proteinuria on the other tissues cannot be excluded.

The results presented here support the hypothesis that lethality associated with nephrin deficiency is due to loss of podocyte function. However, the observed progressing kidney abnormalities and substantial proteinuria suggest that expression of rat nephrin at a level comparable with the level of endogenous nephrin as such is not sufficient for the rescue of all nephrin functions in the podocytes of nephrin deficient mice. The expression of the rat nephrin protein is sufficient for the formation and maintenance of a morphologically normal slit diaphragm structure in the rescued rNeph/mNeph ${ }^{-1-}$ mice, as shown by electron microscopy. However, restoration of the slit diaphragm architecture appeared not to be sufficient for full complementation. The main abnormalities found in the podocytes of rescued mice are changes in the expression and localization of proteins involved in nephrin phosphorylation and signaling. This is an indication that impaired nephrin mediated intracellular signaling, another important function of nephrin, although not well understood, might cause incomplete complementation in the rescued $\mathrm{rNeph} / \mathrm{mNeph}^{-1-}$ mice. The mouse model presented here will be very instrumental to study these aspects of nephrin function in great detail. If the observed impaired nephrin signaling is caused by a disturbed early development of the kidney in absence of endogenous nephrin, our observations may have strong implications for gene therapy in CNF patients. When lack of correct nephrin expression during organogenesis results in irreversible changes in the podocytes of the adult kidney, the expression of nephrin from an exogenous expression vector introduced after birth is unlikely to restore kidney function.

\section{Acknowledgments}

We thank Dr. Lawrence Holzman for providing the podocin promoter and Dr. When Hwa Lee for the Core construct. Special acknowledgments are also due to Mrs. Kristiina Nokelainen, Mr. Jarmo Koponen, Mrs. Kirsi Salonen, and Mrs. Agnes Viherä for their excellent technical support. 


\section{References}

1. Rapola J: Congenital nephrotic syndrome. Pediatr Nephrol 1987 , $1: 441-446$

2. Kestila M, Lenkkeri U, Mannikko M, Lamerdin J, McCready P, Putaala $H$, Ruotsalainen V, Morita T, Nissinen M, Herva R, Kashtan CE, Peltonen L, Holmberg C, Olsen A, Tryggvason K: Positionally cloned gene for a novel glomerular protein-nephrin-is mutated in congenital nephrotic syndrome. Mol Cell 1998, 1:575-582

3. Lenkkeri U, Mannikko M, McCready P, Lamerdin J, Gribouval O, Niaudet PM, Antignac CK, Kashtan CE, Homberg C, Olsen A, Kestila M, Tryggvason K: Structure of the gene for congenital nephrotic syndrome of the finnish type (NPHS1) and characterization of mutations. Am J Hum Genet 1999, 64:51-61

4. Hallman N, Hjelt L: Congenital nephrotic syndrome. J Pediatr 1959, 55:152-162

5. Tryggvason K, Kouvalainen K: Number of nephrons in normal human kidneys and kidneys of patients with the congenital nephrotic syndrome. A study using a sieving method for counting of glomeruli. Nephron 1975, 15:62-68

6. Tryggvason K: Morphometric studies on glomeruli in the congenital nephrotic syndrome. Nephron 1978, 22:544-550

7. Patrakka J, Kestila M, Wartiovaara J, Ruotsalainen V, Tissari P, Lenkkeri U, Mannikko M, Visapaa I, Holmberg C, Rapola J, Tryggvason K, Jalanko $\mathrm{H}$ : Congenital nephrotic syndrome (NPHS1): features resulting from different mutations in Finnish patients. Kidney Int 2000, 58:972-980

8. Putaala H, Soininen R, Kilpelainen P, Wartiovaara J, Tryggvason K: The murine nephrin gene is specifically expressed in kidney, brain and pancreas: inactivation of the gene leads to massive proteinuria and neonatal death. Hum Mol Genet 2001, 10:1-8

9. Rantanen M, Palmen T, Patari A, Ahola H, Lehtonen S, Astrom E, Floss T, Vauti F, Wurst W, Ruiz P, Kerjaschki D, Holthofer H: Nephrin TRAP mice lack slit diaphragms and show fibrotic glomeruli and cystic tubular lesions. J Am Soc Nephrol 2002, 13:1586-1594

10. Putaala H, Sainio K, Sariola H, Tryggvason K: Primary structure of mouse and rat nephrin cDNA and structure and expression of the mouse gene. J Am Soc Nephrol 2000, 11:991-1001

11. Moeller MJ, Sanden SK, Soofi A, Wiggins RC, Holzman LB: Two gene fragments that direct podocyte-specific expression in transgenic mice. J Am Soc Nephrol 2002, 13:1561-1567

12. Moeller MJ, Sanden SK, Soofi A, Wiggins RC, Holzman LB: Podocytespecific expression of cre recombinase in transgenic mice. Genesis 2003, 35:39-42

13. Utomo AR, Nikitin AY, Lee WH: Temporal, spatial, and cell typespecific control of Cre-mediated DNA recombination in transgenic mice. Nature Biotechnol 1999, 17:1091-1096

14. Juhila J, Roozendaal R, Lassila M, Verbeek SJ, Holthofer H: Podocyte cell-specific expression of doxycycline inducible cre recombinase in mice. J Am Soc Nephrol 2006, 17:648-654

15. Sainio K: Experimental methods for studying urogenital development London, Academic Press, 2003, pp 327-328

16. Perl AK, Tichelaar JW, Whitsett JA: Conditional gene expression in the respiratory epithelium of the mouse. Transgenic Res 2002, 11:21-29

17. Jha VK, Jayachandran C, Singh MK, Singh SD: Pharmacokinetic data on doxycycline and its distribution in different biological fluids in female goats. Vet Res Commun 1989, 13:11-16

18. Irwin S: Comprehensive observational assessment: la. A systematic, quantitative procedure for assessing the behavioral and physiologic state of the mouse. Psychopharmacologia 1968, 13:222-257

19. Ahola $H$, Heikkila $E$, Astrom E, Inagaki M, Izawa I, Pavenstadt $H$, Kerjaschki D, Holthofer $\mathrm{H}$ : A novel protein, densin, expressed by glomerular podocytes. J Am Soc Nephrol 2003, 14:1731-1737

20. Lehtonen S, Ora A, Olkkonen VM, Geng L, Zerial M, Somlo S, Lehtonen $\mathrm{E}$ : In vivo interaction of the adapter protein CD2-associated protein with the type 2 polycystic kidney disease protein, polycystin-2. J Biol Chem 2000, 275:32888-32893

21. Inoue $T$, Yaoita E, Kurihara $H$, Shimizu F, Sakai T, Kobayashi $T$, Ohshiro K, Kawachi $H$, Okada H, Suzuki H, Kihara I, Yamamoto T: FAT is a component of glomerular slit diaphragms. Kidney Int 2001, 59:1003-1012
22. Li H, Zhu J, Aoudjit L, Latreille M, Kawachi H, Larose L, Takano T: Rat nephrin modulates cell morphology via the adaptor protein Nck. Biochem Biophys Res Commun 2006, 349:310-316

23. Ruotsalainen $V$, Ljungberg $P$, Wartiovaara J, Lenkkeri U, Kestila M, Jalanko $\mathrm{H}$, Holmberg C, Tryggvason K: Nephrin is specifically located at the slit diaphragm of glomerular podocytes. Proc Natl Acad Sci USA 1999, 96:7962-7967

24. Holthofer $H$, Ahola $H$, Solin ML, Wang S, Palmen T, Luimula P Miettinen A, Kerjaschki D: Nephrin localizes at the podocyte filtration slit area and is characteristically spliced in the human kidney. Am J Pathol 1999, 155:1681-1687

25. Holzman LB, St John PL, Kovari IA, Verma R, Holthofer H, Abrahamson DR: Nephrin localizes to the slit pore of the glomerular epithelial cell. Kidney Int 1999, 56:1481-1491

26. Liu L, Aya K, Tanaka H, Shimizu J, Ito S, Seino Y: Nephrin is an important component of the barrier system in the testis. Acta Med Okayama 2001, 55:161-165

27. Zanone MM, Favaro E, Doublier S, Lozanoska-Ochser B, Deregibus MC, Greening J, Huang GC, Klein N, Cavallo Perin P, Peakman M, Camussi G: Expression of nephrin by human pancreatic islet endothelial cells. Diabetologia 2005, 48:1789-1797

28. Palmen T, Ahola H, Palgi J, Aaltonen P, Luimula P, Wang S, Jaakkola I, Knip M, Otonkoski T, Holthofer $\mathrm{H}$ : Nephrin is expressed in the pancreatic beta cells. Diabetologia 2001, 44:1274-1280

29. Beall MH, Amidi F, Gayle DA, Wang S, Beloosesky R, Ross MG: Placental and fetal membrane Nephrin and Neph1 gene expression: response to inflammation. J Soc Gynecol Investig 2005, 12:298-302

30. Astrom E, Rinta-Valkama J, Gylling M, Ahola H, Miettinen A, Timonen $\mathrm{T}$, Holthofer $\mathrm{H}$ : Nephrin in human lymphoid tissues. Cell Mol Life Sci 2006, 63:498-504

31. Mahan JD, Mauer SM, Sibley RK, Vernier RL: Congenital nephrotic syndrome: evolution of medical management and results of renal transplantation. J Pediatr 1984, 105:549-557

32. Holmberg C, Antikainen M, Ronnholm K, Ala Houhala M, Jalanko H Management of congenital nephrotic syndrome of the Finnish type. Pediatr Nephrol 1995, 9:87-93

33. Kuusniemi AM, Kestila M, Patrakka J, Lahdenkari AT, Ruotsalainen V, Holmberg C, Karikoski R, Salonen R, Tryggvason K, Jalanko H: Tissue expression of nephrin in human and pig. Pediatr Res 2004, 55:774-781

34. Laakkonen $\mathrm{H}$, Lonnqvist T, Uusimaa J, Qvist E, Valanne L, Nuutinen M, Ala-Houhala M, Majamaa K, Jalanko H, Holmberg C: Muscular dystonia and athetosis in six patients with congenital nephrotic syndrome of the Finnish type (NPHS1). Pediatr Nephrol 2006, 21:182-189

35. Guo G, Morrison DJ, Licht JD, Quaggin SE: WT1 activates a glomerular-specific enhancer identified from the human nephrin gene. J Am Soc Nephrol 2004, 15:2851-2856

36. Wagner N, Wagner KD, Xing Y, Scholz H, Schedl A: The major podocyte protein nephrin is transcriptionally activated by the Wilms tumor suppressor WT1. J Am Soc Nephrol 2004, 15:3044-3051

37. Hammes A, Guo JK, Lutsch G, Leheste JR, Landrock D, Ziegler U, Gubler MC, Schedl A: Two splice variants of the Wilms' tumor 1 gene have distinct functions during sex determination and nephron formation. Cell 2001, 106:319-329

38. Jones N, Blasutig IM, Eremina V, Ruston JM, Bladt F, Li H, Huang H, Larose L, Li SS, Takano T, Quaggin SE, Pawson T: Nck adaptor proteins link nephrin to the actin cytoskeleton of kidney podocytes. Nature 2006, 440:818-823

39. Luimula $\mathrm{P}$, Ahola H, Wang SX, Solin ML, Aaltonen P, Tikkanen I, Kerjaschki D, Holthofer $\mathrm{H}$ : Nephrin in experimental glomerular disease. Kidney Int 2000, 58:1461-1468

40. Verma R, Kovari I, Soofi A, Nihalani D, Patrie K, Holzman LB: Nephrin ectodomain engagement results in Src kinase activation, nephrin phosphorylation. Nck recruitment, and actin polymerization. J Clin Invest 2006, 116:1346-1359

41. Tryggvason K, Pikkarainen T, Patrakka J: Nck links nephrin to actin in kidney podocytes. Cell 2006, 125:221-224

42. Jones N, New LA, Fortino MA, Eremina V, Ruston J, Blasutig IM, Aoudjit L, Zou Y, Liu X, Yu GL, Takano T, Quaggin SE, Pawson T: Nck proteins maintain the adult glomerular filtration barrier. J Am Soc Nephrol 2009, 20:1533-1543 